\title{
LA NATURALEZA NO ALIMENTARIA DE LA PORCIÓN CONYUGAL O CONVIVENCIAL EN COLOMBIA*
}

\section{THE NON-SUPPORT NATURE OF THE LEGAL RIGHT SHARE IN COLOMBIA}

\author{
Yadira Elena Alarcón-Palacio** \\ Juan José Gómez-Neira*** \\ Fecha de recepción: 15 de octubre de 2015 \\ Fecha de aceptación: 15 de noviembre de 2015 \\ Disponible en linea: 30 de noviembre de 2015
}

\section{Para citar este artículo/To cite this article}

\begin{abstract}
Alarcón-Palacio, Yadira Elena \& Gómez-Neira, Juan José, La naturaleza no alimentaria de la porción conyugal o convivencial en Colombia, 131 Vniversitas, 65-106 (2015). http://dx.doi.org/10.11144/Javeriana.vj131.napc doi:10.11144/Javeriana.vj131.napc
\end{abstract}

* El presente trabajo responde a un producto vinculado al Grupo de Investigación en Derecho Privado de la Pontificia Universidad Javeriana, mediante el proyecto Análisis de las nuevas tendencias del derecho de familia en el marco del Estado Constitucional de Derecho, al que pertenece esta contribución. Convocatoria Interna ID 00005765.

** Profesora asociada, Facultad de Ciencias Jurídicas, Pontificia Universidad Javeriana (Bogotá). ORCID 0000-0002-8635-6264. Doctora en derecho privado, social y económico, Universidad Autónoma de Madrid, UAM. Magíster en necesidades-derechos de la infancia y la adolescencia, de la misma Universidad. Especialista en derecho de familia, Pontificia Universidad Javeriana (Colombia). Abogada, Universidad del Norte (Colombia). Exeditora de la revista Vniversitas, Pontificia Universidad Javeriana. Líder del Grupo de Investigación en Derecho Privado y del Proyecto de Investigación de la misma Universidad. Contacto: yalarcon@ javeriana.edu.co

*** Magistrado Suplente en la Audiencia Provincial de Las Palmas de Gran Canaria (España). ORCID 0000-0002-9747-9489. Doctorando en el área de Derecho civil, Universidade de Santiago de Compostela (España). Máster en Derecho privado, Universidade de Santiago de Compostela (España). Experto en Derecho civil en Galicia, Universidade de Santiago de Compostela (España). Licenciado en derecho (rama económico-empresarial), Universidade de Vigo (España). Director de la revista Cuaderno Electrónico de Estudios Jurídicos (CEEJ). Presidente del Círculo Académico de Estudios Jurídicos. Contacto: juanpeneira@gmail.com 


\section{RESUMEN}

La presente obra tiene por objeto resolver una de las cuestiones con mayor conflictividad, hoy, en torno a los derechos sucesorales del cónyuge o compañero permanente supérstite: la naturaleza jurídica de la porción conyugal. Concretamente, centraremos el estudio en la corriente clásica que se caracteriza por atribuir a la porción conyugal una naturaleza alimentaria, llegando hasta el punto de determinar mediante un análisis inductivo-deductivo que esta naturaleza no resulta aplicable a la porción conyugal, debido a la imposibilidad de encuadrar en esta última los caracteres y presupuestos imperativos de las obligaciones alimentarias. Por ende, ha de entenderse la porción conyugal como una institución de naturaleza sucesoral, consistente en la vocación, tanto testamentaria como ab intestato, al cónyuge o compañero como heredero a título singular, en todos los órdenes sucesorales. Responde la porción a la consideración de un legado ex lege con finalidad alimentaria constituido a favor del cónyuge o compañero en todos los órdenes.

Palabras clave: porción conyugal; naturaleza; alimentos; derecho sucesoral; compañero; compensatoria 


\section{ABSTRACT}

This work aims to solve a currently very conflictive issue regarding the inheritance rights of the spouse or surviving common law spouse: the legal nature of the legal right share. Specifically, we will focus our study on the classic current, characterized by giving the legal right share a support nature, and by means of an inductive-deductive analysis we come to determine that this nature is not applicable to the legal right share. This is due to the impossibility to fit in the mandatory characteristics and assumptions of support obligations. Thus, legal right share has to be understood as an inheritance institution in nature, consisting of the inheritance, with or without a will, to the spouse or common law spouse, in all inheritance orders. The legal right share corresponds to considering an inheritance by law, constituted for support purposes, in favor of the spouse or common law spouse, in all orders.

Keywords: legal right share; nature; support; inheritance law; spouse; compensatory

\section{SUMARIO}

I. LA INDETERMINACIÓN DE LA NATURALEZA DE LA PORCIÓN CONYUGAL EN EL SISTEMA JURÍDICO ACTUAL. II. El DESLINDE DE LA PORCIÓN CONYUGAL DE SU CONDICIÓN ALIMENTARIA. - A. La no aplicación de los caracteres de las obligaciones alimentarias a la porción conyugal o convivencial. -B. Los presupuestos taxativos de las obligaciones alimentarias y su no concurrencia en la porción conyugal o del compañero.- 1 . El vínculo causal como requerimiento taxativo para el nacimiento de la obligación alimentaria y su extensión a la porción conyugal o convivencial.- 2- El estado de necesidad, su influencia en el nacimiento de la obligación alimentaria y su configuración inexacta entorno a la porción.- 3. La capacidad económica como último presupuesto esencial de la obligación alimentaria. Su aplicabilidad a la porción conyugal o convivencial.-ConcLusión.- BIBLIOGRAFÍA. 


\section{LA INDETERMINACIÓN DE LA NATURALEZA DE LA PORCIÓN CONYUGAL EN EL SISTEMA JURÍDICO ACTUAL}

El ordenamiento jurídico colombiano contempla en el ámbito sucesorio el establecimiento de una institución favorable al cónyuge supérstite: la porción conyugal ${ }^{1}$. Este derecho sucesoral del cónyuge o compañero del causante ${ }^{2}$, fácilmente comprensible y determinable según las disposiciones del legislador, ha dado lugar — durante estos últimos tiempos - a resoluciones contradictorias entre los diversos órganos estatales que, según su propio ámbito competencial, han resuelto de diverso modo; llegando hasta el irrisorio de ofrecer consideraciones contrapuestas acerca de la misma institución jurídica ${ }^{3}$.

Resulta, cuando menos, incomprensible esta interpretación discordante acerca de la naturaleza de la porción conyugal, pues la propia Constitución Política garantiza a todas las personas «la misma protección y trato de las autoridades y gozarán de los mismos derechos, libertades y oportunidades sin ninguna discriminación (...) $\rangle^{4}$. No obstante, actualmente, nos encontramos ante un siste-

1 La porción conyugal ha sido regulada por el legislador en el Capítulo II del Título V del Libro III del Código Civil Colombiano, Ley 57 de 1887, consignada como una asignación forzosa que el testador está obligado a hacer. Ley 57 de 1887, Código Civil, art. 1226. Disponible en: http://www.secretariasenado.gov.co/senado/basedoc/codigo_civil.html

2 La Corte Constitucional declaró exequible el artículo 1226 y todos los demás referentes a esta institución, siempre y cuando se entienda que a la porción conyugal en ellos regulada, también tienen derecho el compañero o compañera permanente y la pareja del mismo sexo. Corte Constitucional, Sentencia C-283-11, 13 de abril de 2011, magistrado ponente Jorge Ignacio Pretelt-Chaljub. Disponible en: http://www.corteconstitucional.gov.co/relatoria/2011/C-283-11. htm

3 Baste solo mencionar, a modo de ejemplo de la contradicción, las siguientes resoluciones: Corte Suprema de Justicia, Sentencia de 18 de julio de 1944. Corte Suprema de Justicia, Sentencia de 21 de octubre de 1954. Corte Suprema de Justicia, Sala de Casación Civil, Sentencia de 21 de marzo de 1969. Corte Constitucional, Sentencia C-283-11, 13 de abril de 2011, magistrado ponente Jorge Ignacio Pretelt-Chaljub. Disponible en: http://www.corteconstitucional.gov. co/relatoria/2011/C-283-11.htm. Consejo de Estado, Sentencia 2410-04, 20 de septiembre de 2007, radicado 76001233100019990145301, consejero ponente Jesús María Lemos-Bustamante. Disponible en: http://consejo-estado.vlex.com.co/vid/-410740250, http://190.24.134.114:8080/ WebRelatoria/ce/index.xhtml. Consejo de Estado, Sentencia 2176-07, 26 de junio de 2008, radicado 25000-23-25-000-2001-02614-01, consejero ponente Gustavo Eduardo GómezAranguren. Disponible en: http://190.24.134.114:8080/WebRelatoria/ce/index.xhtml. Consejo de Estado, Sentencia 0638-08, 30 de julio de 2009, radicado 68001-23-15-000-2001-02594-01, consejero ponente Gerardo Arenas-Monsalve. Disponible en: http://190.24.134.114:8080/ WebRelatoria/ce/index.xhtml. Consejo de Estado, Sentencia 1659-09, 27 de mayo de 2010, radicado 19001-23-31-000-2001-01669-01, consejero ponente Víctor Alvarado-Ardila. Disponible en: http://190.24.134.114:8080/WebRelatoria/ce/index.xhtml

4 En este sentido, Constitución Política [Const], 7 de julio de 1991, artículo 13. Versión corregida, 
ma doblemente infraccionista de los derechos que atienden a los ciudadanos. Decimos duplamente quebrantatorio porque, de una parte, los ciudadanos — siendo iguales ante la ley - son tratados de forma distinta según el órgano que dicte la resolución; $y$, en adición, a lo único que conduce es a una inseguridad jurídica dentro del propio ordenamiento, de modo que no se cumple el deber de garantizar la constitucionalidad de las normas ni su adecuada inserción en el propio sistema jurídico, lo cual genera antinomias en su interpretación y aplicación.

Ahora bien, alguno de los lectores se preguntará a qué viene tanto revuelo sobre una institución que lleva conviviendo de forma pacífica en el ordenamiento jurídico colombiano desde que fue tomada por Andrés Bello de la legislación española ${ }^{5}$. Pues bien, la réplica a esta cuestión radica en la cuádruple naturaleza jurídica que se atribuye a la porción conyugal de forma incongruente. Piénsese que una institución jurídica ha de responder a un único fundamento de ser, a una única consideración jurídica o naturalística ${ }^{6}$, pues una

116 Gaceta Constitucional, 20 de julio de 1991, disponible en: http://www.secretariasenado. gov.co/senado/basedoc/constitucion_politica_1991.html

5 Andrés Bello (1781-1865) configura la institución de la porción conyugal tomando como punto de referencia la figura de la cuarta marital originaria del Derecho romano y recogida, posteriormente, por la legislación española. Es conveniente observar, al respecto, lo expuesto en Andrés Bello, Código Civil de la República de Chile, tomo III (Ediciones de la Presidencia de la República, Caracas, 1973).

No obstante, si se pretende fijar los antecedentes exactos de los derechos sucesorales del cónyuge viudo, hay que remontarse a la siguiente cronología normativa, así pues: En Derecho romano, como antecedente de institución sucesoria entre cónyuges, encontramos la cuarta concedida a la viuda por las Novelas 53 y 117, del emperador Justiniano, que reinó del 1 de agosto de 527 hasta 13 de noviembre de 565. Sin embargo, no puede hablarse de un derecho sucesoral strictu sensu, ya que surge como consecuencia de la deuda alimenticia para la viuda pobre o que no dispone de dote, la cual le permita cubrir los medios de subsistencia. En cuanto a las legislaciones germánicas de la Edad Media - Lex Wisigothorum, Lex Baiovariorum y Lex Burgundionum - hay un avance en el reconocimiento de derechos sucesorales a favor del cónyuge viudo, específicamente del cónyuge de género femenino, estableciendo cuotas en concepto de usufructo a su favor.

En lo tocante a la legislación española debe mentarse, en lo concerniente a los derechos del cónyuge viudo: la Ley 14, Título II, Libro IV, del Liber Iudiciorum de Recesvinto (654 d.C.); la Legislación de los Fueros Municipales; la Ley 7a , Título XIII, de la Partida $6^{\text {a }}$; el artículo 773 del Proyecto de Código Civil de 1851; la base 17 de la Ley de 11 de mayo de 1888; el artículo 834 en la versión original del Código Civil de 1889; la reforma del Código Civil de 1889 operada el 24 de abril de 1958; la reforma del Código Civil de 1889 de 4 de julio de 1970; entre otras. Al respecto de esta evolución histórica, ver lo expuesto por Quintus Mucius-Scaevola y Felipe Sánchez-Román. Quintus Mucius-Scaevola, Código civil comentado y concordado extensamente, Vol. XIV, 697 ss. (Instituto Editorial Reus, Madrid, 1949-1965). Felipe SÁnCheZ-RomÁn, Estudios de Derecho civil, Vol. VI-2, 798 ss. (Sucesores de Rivadeneyra, Madrid, 1850-1916).

6 Enrique Pedro Haba-Müller, Axiología jurídica fundamental. Bases de valoración en el discurso jurídico, 59-61 (Editorial de la Universidad de Costa Rica, San José de Costa Rica, 1934). 
institución no puede ser coetáneamente: alimentaria, crediticia, compensatoria y sucesoria.

La divergencia en cuanto a la naturaleza de la porción conyugal o convivencial ${ }^{7}$ deriva de esta cuádruple asignación, situación que se ve agravada por la no existencia de una unidad de criterio a la hora de resolver las controversias que se plantean en la realidad social-familiar. Así pues, dependiendo del caso concreto y del órgano resolutorio la porción conyugal gozará de una u otra consideración; de modo que al ciudadano le resulta totalmente imposible determinar a priori y objetivamente cuáles serán las consecuencias jurídicas que se pueden derivar de su situación familiar o social. Por ende, resulta ilógico pensar en la idea de que existen unas condiciones jurídicas tendientes a promover la igualdad real y efectiva entre todos los ciudadanos.

A pesar de lo expuesto anteriormente, ha de creerse que aquel que critica una realidad - ya sea social o jurídica - ha de tender a ofrecer sus razones, así como las soluciones que desde su punto de vista serían las más coherentes para erradicar este entorno jurídicamente reprochable. Por consiguiente, a nuestro parecer, la falta de exactitud al respecto de la conceptualización y naturaleza de la porción conyugal no es directamente reprochable a los actuales magistrados o consejeros ponentes, pues estos han partido de una consideración —3/4desde nuestra consideración mal establecidadada por Andrés Bello y secundada por otros autores como Manuel Somarriva ${ }^{8}$. No obstante, aquellos como aplicadores de las normas jurídicas habrán de tender a que los ciudadanos gocen de un trato igualitario y no discriminatorio, al cual en la actualidad se encuentran íntegramente sometidos.

Como adelantábamos, creemos que la interpretación dada por Bello de la cuarta marital - y que ha pasado a ser el fundamento de la porción conyugal — no es del todo exacta ya que, aun aten-

7 Conyugal o convivencial nos parecen términos más incluyentes pues el adjetivo marital viene del latín maritālis, perteneciente o relativo al marido o a la vida conyugal, lo cual incluso puede designar parejas del mismo sexo masculinas, pero que resulta excluyente al tratarse de parejas femeninas.

8 Manuel Somarriva-Undurraga sostiene que la institución de la porción conyugal es originaria de Bello, por tres razones: 1. En las legislaciones precursoras solo se otorgaba a la viuda. 2. Tenía un límite en cuanto a su cantidad. 3. En el derecho romano y en la legislación española, la cuarta marital respondía a un carácter netamente alimenticio. Manuel SomarrivaUndurraga, Evolución del Código Civil chileno (Editorial Temis, Bogotá, 1973). 
diendo a razones alimentarias - como así se manifiesta en la propia definición de la institución -9 , no respeta el criterio de la necesidad en la figura del beneficiario o cónyuge/compañero del causante supérstite. Adviértase que el propio legislador fija como monto de la porción conyugal la cuarta parte de los bienes de la persona difunta, respecto a todos los órdenes de sucesorios, excepto en el de los descendientes.

En consecuencia, estamos ante una consideración que nos puede llevar a la situación absurda en la que el cónyuge o el compañero del causante supérstite tenga derecho a la porción conyugal por ser considerado "pobre", pero tenga totalmente satisfecha su congrua subsistencia sin necesidad de acudir a ese derecho sucesorio ${ }^{10}$.

Sin perjuicio de que esta cuestión sea tratada con mayor detalle en un momento próximo, ante esta situación cabe plantearse si la porción conyugal responde estrictamente a una naturaleza alimentaria o si, por el contrario, ha de investirse a la institución de otra concepción naturalística. Esta nueva consideración surge de la propia configuración de la obligación alimentaria, pues es requisito sine qua non para hablar de un acreedor alimentario que en este concurra la necesidad alimentaria - circunstancia que puede darse o no en el titular del derecho a la porción conyugal ${ }^{11}$.

Esbozada la situación actual en cuanto a la regulación y consideración jurídica de la porción conyugal o convivencial, así como el establecimiento de unas pautas introductorias que nos sirven de entrada para el análisis primario de la materia a tratar, resulta adecuado proceder a una disquisición de mayor envergadura a través de los sucesivos apartados que integran esta breve obra.

9 Ley 57 de 1887, Código Civil, art. 1230. Disponible en: http://www.secretariasenado.gov.co/ senado/basedoc/codigo_civil.html

10 Ya hacía referencia a esta posibilidad José Clemente Fabres al manifestar que el carácter puramente alimenticio de la porción conyugal no era rigurosamente exacto. En este sentido, José Clemente Fabres-Fernández, Obras completas de José Clemente Fabres, Tomo II: La porción conyugal según el Código Civil chileno (Editorial Imprenta Cervantes, Santiago de Chile, 1908).

11 En lo tocante a esta cuestión, adviértase la regulación del Código Civil Colombiano, Ley 57 de 1887, relativa a "los alimentos que se deben por ley a ciertas personas". Ley 57 de 1887, Código Civil. Disponible en: http://www.secretariasenado.gov.co/senado/basedoc/codigo_civil.html 


\section{EL DESLINDE DE LA PORCIÓN CONYUGAL DE SU CONDICIÓN ALIMENTARIA}

La condición alimentaria de la porción conyugal o convivencial responde a la concepción y naturaleza clásica que la doctrina tradiciona $1^{12}$ y la jurisprudencia ${ }^{13}$ han venido sustentando en el tiempo. Esta conceptualización encuentra su piedra angular en la obligación de socorro y ayuda mutua que han de brindarse los cónyuges o convivientes en todas las circunstancias de la vida ${ }^{14}$; a la que se suma la obligación alimentaria ex lege entre cónyuges y excónyuges - esta última respecto del cónyuge divorciado o separado de cuerpos culpable a favor del no culpable- ${ }^{15}$.

Esta interpretación naturalística de la porción parece ser la que pudiera derivarse del espíritu del legislador, en tanto que la conceptúa en el artículo 1230 Código Civil Colombiano, CCC, como "aquella parte del patrimonio de una persona difunta que la ley asigna al cónyuge sobreviviente que carece de lo necesario para su congrua subsistencia". A pesar de esta consideración, si atendemos a la propia redacción llevada a cabo por el legislador, podremos observar que más que una naturaleza jurídica, se pretende dotar al derecho sucesoral del cónyuge o conviviente supérstite de una finalidad alimentaria.

A la vista de lo anterior, cabría pensar que la porción conyugal o convivencial responde a una naturaleza sucesoria finalísticamente

12 Fernando Vélez dice: "la porción conyugal es una especie de pensión alimenticia entregada en forma global al cónyuge sobreviviente". FERnANDo VÉLEz, Estudios sobre el derecho civil colombiano, Vol. IV, 384 (Editorial Imprenta París-América, Medellín, 1909). Yadira AlarcónPalacio se refiere a la porción como: "es una de las especies de asignación forzosa destinada al cónyuge que no posee los recursos económicos necesarios para posibilitar su íntegra y digna subsistencia (...). El axioma de la figura se encuentra en el deber de auxilio mutuo de los cónyuges, el cual no solo se debe limitar a la vida de los mismos, sino también a su sobrevivencia después de la muerte de alguno de ellos". Yadira Elena Alarcón-Palacio, Reconocimiento por vía de interpretación constitucional de los derechos sucesorios del conviviente "supérstite" en Colombia, en Estudios jurídicos en homenaje al profesor José María Miquel, Vol. I, 125-168 (Luis Díez-Picazo y Ponce de León, coord., Aranzadi, Navarra, 2014).

13 La Sentencia de Casación Civil de la Corte Suprema de Justicia del 21 de marzo de 1969 cuando dispone que "la porción conyugal es una prestación sui generis de carácter alimentario".

14 El artículo 176 del Código Civil colombiano contempla estas obligaciones como reglas generales entre cónyuges. Ley 57 de 1887, Código Civil. Disponible en: http://www.secretariasenado. gov.co/senado/basedoc/codigo_civil.html

15 En cuanto a los titulares del derecho de alimentos habrá de atenderse lo establecido en el artículo 411 del Código Civil colombiano ss. Ley 57 de 1887, Código Civil. Disponible en: http://www.secretariasenado.gov.co/senado/basedoc/codigo_civil.html 
determinada ab initio por el legislador, esto es: la finalidad alimentaria tendiente a garantizar la congrua subsistencia del cónyuge o conviviente del de cuius. No obstante, afirmar esto de entrada sin aportar la correspondiente fundamentación jurídica sería tanto como no decir nada, por tal motivo será necesario llevar a cabo un análisis de la configuración jurídica de la obligación alimentaria ex lege, lo que nos permitirá deslindar esta institución de la porción conyugal o convivencial.

\section{A. La no aplicación de los caracteres de las obligaciones alimentarias a la porción conyugal o convivencial}

La obligación alimentaria ex lege presenta caracteres propios que implican cierta autonomía e independencia, tanto en el terreno sustantivo como en el procesal; y así se considera civilmente como un crédito a exigir y una deuda a satisfacer, por fundamentales razones de interés familiar y social, que se traducen en las notas siguientes: a) "irrenunciabilidad" del derecho a su percepción, aunque puedan renunciarse las pensiones alimentarias atrasadas (art. 426 del Código Civil colombiano); b) "intransmisibilidad" del mismo derecho, con idéntica excepción (art. 426 del Código Civil colombiano); c) falta de aptitud para ser opuesta su "compensación" con lo que el alimentista deba, por cualquier concepto, al que ha de prestar los alimentos (art. 425 del Código Civil colombiano), con la tan repetida excepción en cuanto a las pensiones atrasadas; y d) no ser susceptible el derecho a los alimentos futuros de ser materia de los contratos de compraventa y de cesión (art. 424 del Código Civil colombiano).

La determinación de estos caracteres de la obligación alimentaria nos lleva, de entrada, a excluir la porción conyugal o convivencial de su naturaleza alimentaria, pues difícilmente encuadrable resulta esta en las peculiaridades propias de la deuda alimentaria ${ }^{16}$. En consecuencia, a modo de ejemplo y de manera sucinta, procede-

16 "Deuda alimentaria" es la que afecta a una persona, llamada alimentante, que resulta obligada a prestar a otra, llamada asimismo alimentario, lo indispensable para cubrir todas sus necesidades perentorias, o dicho con palabras legales, las necesidades mínimas para subsistir mientras aquellas persistan. 
remos al análisis comparativo de alguno de estos caracteres. Así pues, en lo que respecta al carácter de la irrenunciabilidad, podemos decir que no existe norma dentro del ordenamiento jurídico colombiano que obligue al cónyuge o al conviviente supérstite a no renunciar al derecho sucesoral que constituye la porción conyugal o convivencial. La porción, como institución hereditaria que es, habrá de regirse ya no solo por las normas generales de aceptación y repudio ${ }^{17}$ sino, también, por las normas particulares que a ella se refieren ${ }^{18}$. Luego, el cónyuge o conviviente podrá repudiar a su derecho - objetivamente considerado - en la sucesión del causante desde el momento de la muerte de aquel o aceptarlo una vez se ha deferido, todo ello sin entrar a valorar si concurre o no la condición de pobreza respecto a su persona. Una vez valorada la situación de pobreza y transformada la mera expectativa en una titularidad efectiva sobre el derecho a la porción será cuando entre en juego la doble modalidad de aceptación-renuncia que contempla el artículo 1235 del Código Civil colombiano.

Otro aspecto reseñable deriva de la posibilidad de que se dé en la figura del cónyuge o conviviente la condición de heredero universal o singular y titular del derecho a la porción de modo concurrente; de manera que al ser instituciones hereditarias independientes ${ }^{19}$ podrá aceptar la primera y repudiar la segunda o a la inversa, salvo que la primera se encuentre gravada a menos que se defiera separadamente ${ }^{20}$.

En definitiva, como se ha venido demostrando, el carácter de la irrenunciabilidad propio de la obligación alimentaria no resulta predicable de la porción conyugal o convivencial, circunstancia que, de inicio, permite descartar la naturaleza alimentaria de la porción conyugal.

17 Atiéndase a lo señalado en los artículos 1282 del Código Civil colombiano ss. Francisco LLEDÓ-YAGÜE, La sucesión mortis causa: delación y la incapacidad para suceder, aceptación y repudiación de la herencia, las legítimas, las reservas, comunidad hereditaria y la partición (Dykinson, Madrid, 2012).

18 El legislador ha previsto una modalidad opcional de aceptación en lo que a la porción conyugal o convivencial se refiere: el cónyuge o conviviente podrá optar entre retener lo que posea o se le deba, renunciando a la porción, o pedir la porción abandonando sus otros bienes y derechos a favor de la masa hereditaria del causante - artículo 1235 del Código Civil colombiano -.

19 El artículo 1226 del Código Civil colombiano contempla de un modo autónomo las asignaciones forzosas y la condición de heredero, sin que la primera asignación excluya la segunda.

20 Todo ello en aplicación del criterio general de aceptación y repudio simultáneo previsto en el artículo 1286 del Código Civil colombiano. 
Junto a este carácter irrenunciable que presenta la obligación alimentaria ex lege, es reseñable el que se refiere a la intransmisibilidad, pues la intransmisibilidad - aun siendo factible respecto de la porción - responde a un contenido claramente distinto.

La intransmisibilidad, en cuanto a la obligación alimentaria, se configura como una intransmisibilidad del derecho a la petición y percepción de los alimentos, derecho del que es titular personalísimo el alimentista ${ }^{21}$. En suma, esta intransmisibilidad se extiende tanto a la deuda como al propio crédito alimenticio, ya que si en el acreedor deja de concurrir la condición de necesidad, el crédito se extingue y del mismo modo se extinguirá la deuda, si el deudor carece de capacidad económica para hacerle frente ${ }^{22}$. Ahora bien, si se diese esta última condición respecto al deudor y el acreedor siguiese presentando un estado de necesidad, no se produciría una transmisión de la deuda a un nuevo deudor solvente sino que habría de constituirse una nueva obligación alimenticia entre aquel y este último. Asimismo, al ser una obligación de carácter personalísimo no resulta predicable la transmisibilidad del derecho de alimentos mortis causae ${ }^{23}$.No obstante, el legislador ha previsto en el artículo 1226 del Código Civil colombiano que estas obligaciones alimenticias atrasadas sean satisfechas conforme a la masa integrante del caudal relicto, ello no quiere decir que estemos ante una transmisión mortis causae de la deuda alimenticia a los herederos del causante,

21 Al respecto del carácter personalísimo de la obligación de naturaleza alimentaria, DoMÉNIco Barbero, Sistema de Derecho privado, Volumen II, 192 (Santiago Sentis-Melendo, trad., Ediciones Jurídicas Europa-América, EJEA, Buenos Aires, 1967).

22 En torno a la extinción de la obligación alimentaria por falta de capacidad en la figura del deudor, sentencia del Tribunal Superior de Justicia y Audiencia Provincial — SAP — de Lleida de 13 de octubre de 1998 en la que se contempla que: "Uno de los presupuestos de la obligación alimenticia, junto con la relación de parentesco y la necesidad del alimentista, es la capacidad económica del alimentante. Sin ella la obligación no llega a nacer. Esta cuantía se calcula según aquella capacidad nacida, por lo que las variaciones en aquella capacidad se traducirán en variaciones de la cuantía; reducida por debajo de cierto límite la capacidad económica del alimentante, se extingue la obligación". Refuerza el mantenimiento, a lo largo del tiempo, de esta postura jurisprudencial, entre otras, la sentencia del Tribunal Superior de Justicia y Audiencia Provincial — SAP — de Santa Cruz de Tenerife de 22 de noviembre de 2012.

23 El legislador ha previsto esta intransmisibilidad en el artículo 424 del Código Civil colombiano. A ella se refieren autores como Ioannis Petri Surdi-Casalensis: "nam obligatio alendi ex parte creditoris dicitur personalis et in personam quia finitur illius morte, et extinguitur cum eius persona”. Ioannis Petri Surdi-Casalensis, Tractatus de alimentis plenissimus, et omni hominum generi, praesertimin praxi et foro, vtilissimus, Título IX, quaest. XIII, número 11 (Stephanum Camonetum, 1602). 
sino ante un crédito del titular del derecho de alimentos contra la masa hereditaria.

Estimamos que sostener la postura contraria, es decir, que la prestación alimentaria impagada en vida del causante pueda gravar activos ajenos a la masa hereditaria, supone establecer una responsabilidad hereditaria ilimitada por deudas personalísimas del de cuius en perjuicio de los demás instituidos herederos ${ }^{24}$.

En cuanto al carácter intransmisible de la porción conyugal o convivencial, ha de señalarse que la restricción opera no en consideración al derecho alimentario o a la propia finalidad de la institución hereditaria que pudiera representar sino al propio derecho sucesoral. Nótese que el llamado por ley, en lo que a la porción conyugal o convivencial se refiere, es el cónyuge o conviviente supérstite $^{25}$ sin que quepa el derecho de representación a que alude el artículo 1041 del Código Civil colombiano.

Por coherencia con lo manifestado, la porción conyugal no podrá ser objeto de transmisión inter vivos o mortis causae, mientras ese derecho sucesorio no se realice efectivamente e integre dentro del patrimonio de su titular. De ahí que una vez integrado como un elemento más del acervo patrimonial del titular de la porción conyugal, este quede libre de cualquier restricción de transmisibilidad. Sin embargo, si la institución hereditaria que representa la porción conyugal fuese satisfecha mediante actos sucesivos - esto es mediante el establecimiento de una renta o capital periódicopodrán transmitirse por acto entre vivos o por causa de muerte el monto de aquellos pagos periódicos o el derecho a reclamarlos en

24 Pone de manifiesto la regla general de confusión de patrimonios del causante y del heredero y, como consecuencia, la ilimitación de la responsabilidad como efecto natural de la aceptación pura y simple. María Paz García-Rubio, La distribución de toda la herencia en legados (Un supuesto de herencia sin heredero) (Civitas, Secretariado de Publicaciones de la Universidad de León, León, 1989). Francisco GINOT DE Llobateras, La responsabilidad del heredero simple por deudas y legados en el derecho común y foral, 3 Anuario de Derecho Civil, 4, 1057-1099, 1081 (1950).

25 El artículo 1040 del Código Civil colombiano prevé entre los llamados a la sucesión intestada la figura del cónyuge supérstite extensible por Sentencia C-238-12, al compañero o compañera permanente de distinto sexo o del mismo sexo que conformó con el causante, a quien sobrevive, una unión de hecho. Llamamiento hereditario que no solo ha de circunscribirse, al respecto de la porción conyugal, en la sucesión abintestato sino, también, en la testamentaria pues el artículo 1226 del Código Civil colombiano configura esta institución hereditaria como una restricción a la facultad de testar del de cuius. Corte Constitucional, Sentencia C-238-12, 22 de marzo de 2012, magistrado ponente Gabriel Eduardo Mendoza-Martelo. Disponible en: http://www.corteconstitucional.gov.co/relatoria/2012/c-238-12.htm 
la que la misma consista ya integrados en el patrimonio del titular o que sin estar integrados o no pagados ya hayan sido devengados, pues se entiende que la finalidad de subsistencia ya se ha extinguido en relación con los mismos; de modo que dejan ya de ser necesarios para la vida y en los cuales no concurren las razones de orden público que los hacen indisponibles, sino que, por el contrario, se convierten en un crédito disponible en el patrimonio del cónyuge o convivencial que puede libremente transigirlo ${ }^{26}$.

El análisis comparativo de estos dos caracteres, existentes en la obligación alimentaria frente a su integración en la porción conyugal, reporta una clara diferenciación entre ambas figuras legales; circunstancia que permite deslindar apriorísticamente la una de la otra.

\section{B. Los presupuestos taxativos de las obligaciones alimentarias y su no concurrencia en la porción conyugal o convivencial}

No solamente es factible proceder a la diferenciación de las obligaciones alimentarias por medio de sus caracteres, sino, también, mediante los requisitos objetivamente previstos en el ordenamiento jurídico. La obligación alimentaria se ha de entender como un deber impuesto a una o varias personas de asegurar la subsistencia de otras, y requiere para su viabilidad la concurrencia de requerimientos taxativos: "situación o estado de necesidad, vínculo causal y capacidad económica del obligado a su prestación ${ }^{27}$ '.Por consiguiente, acaece lógico observar si esos presupuestos de exigibilidad son predicables al respecto de la porción conyugal o convivencial.

26 Adviértase el Fundamento de Derecho Segundo en sentencia del Tribunal Superior de Justicia y Audiencia Provincial de Murcia. España, Tribunal Superior de Justicia y Audiencia Provincial — SAP — de Murcia, Sentencia de 16 de febrero de 1999. En el mismo sentido, las Sentencias del Tribunal Supremo y Tribunales de Valencia. España, Tribunal Supremo, Sentencia de 11 de octubre de 1982. España, Tribunal Supremo, Sentencia de 10 de noviembre de 1987. España, Tribunal Superior de Justicia y Audiencia Provincial — SAP — de Valencia, Sentencia de 23 de febrero de 2001.

27 Alicia Real-Pérez entiende que la obligación entre parientes "constituye una institución jurídica de Derecho de Familia que goza de indudable autonomía (...), se construye este derecho en torno a unos principios peculiares que lo caracterizan y se desenvuelve por obra de unas reglas que le son propias". Alicia Real-Pérez, Comentario a los artículos 142 a 153 del CC, en Comentarios al Código Civil, Tomo II (Volumen II), 1395-1470 (Joaquín José Rams-Albesa \& Rosa María Moreno-Flórez, dirs., Bosch, Barcelona, 2000). 


\section{El vínculo causal como requerimiento taxativo para el nacimiento de la obligación alimentaria y su extensión a la porción conyugal o convivencial}

\section{En este orden de ideas, ha de comenzarse por el análisis del "vínculo} causal" a cuya consideración el legislador señala al cónyuge o compañero permanente entre el primer obligado a prestarse alimentos ${ }^{28}$, incluso una vez extinguido el vínculo matrimonial ${ }^{29}$-al respecto del miembro de la pareja no culpable-o convivencial more uxorio ${ }^{30}$. El legislador ha reconocido en la unión matrimonial y convivencial la existencia de un vínculo lo suficientemente sólido sobre el cual sustentar la imposición de esta obligación alimentaria, que supera incluso la consideración de los lazos consanguíneos.

Ahora bien, este reconocimiento de la obligación-deber de alimentos entre cónyuges o compañeros permanentes requiere una doble matización. Primera, entendida strictu sensu, la obligación ex lege de alimentos solo opera en situaciones de crisis matrimoniales o convivenciales: mientras dura el vínculo jurídico entre aquellos existe un deber de socorro mutuo de carácter económico que obliga a cada una de las partes integrantes de la relación a atender las necesidades de la otra, lo que engloba las necesidades alimentarias ${ }^{31}$.

28 Obsérvese, en este sentido, la prelación de titulares del derecho de alimentos y el orden de preferencia establecido en los artículos 411 y 416 del Código Civil colombiano.

29 El legislador ha optado por mantener la prestación de alimentos a favor del cónyuge no culpable de la causa de divorcio o separación de cuerpos. Resulta un tanto ilógico el mantenimiento de esta postura, ya que el vínculo que los unía ha sido objeto de extinción, por lo que las obligaciones de socorro o ayuda que derivan de ese vínculo también se extinguen con él. Debe pensarse que la extinción de la relación jurídica principal —el vínculo matrimonial o convivencial - conlleva la extinción de cualquier obligación dimanante de la misma, por ende la subsistencia de la obligación alimenticia entre excónyuges no atiende a una razón con base jurídica. No obstante, coincidimos con el mantenimiento de las obligaciones de socorro o ayuda en los supuestos derivados de la causal $6^{\text {a }}$ del artículo 154 del Código Civil colombiano; pues ha de entenderse que por razones de protección a las personas con discapacidad es necesaria la subsistencia del vínculo obligacional. En este sentido, Corte Constitucional, Sentencia C-246-02, 9 de abril de 2002, magistrado ponente Manuel José Cepeda-Espinosa. Disponible en: http://www.corteconstitucional.gov.co/relatoria/2002/C-246-02.htm

30 Esta obligación alimentaria inicialmente prevista por el legislador para los cónyuges y excónyuges no culpables ha de hacerse extensiva, también, a los compañeros permanentes mientras dure el vínculo. Así se desprende de varias sentencias de la Corte Constitucional. Corte Constitucional, Sentencia C-1033-02, 27 de noviembre de 2002, magistrado ponente Jaime Córdoba-Triviño. http://www.corteconstitucional.gov.co/relatoria/2002/c-1033-02.htm. Corte Constitucional, Sentencia C-029-09, 28 de enero de 2009, magistrado ponente Rodrigo Escobar-Gil. Disponible en: http://www.corteconstitucional.gov.co/relatoria/2009/c-029-09. $\mathrm{htm}$. Ahora bien, no cabe hablar de obligación alimentaria a favor del excompañero no culpable, ya que no concurren las causales de culpabilidad en los vínculos de facto.

31 En la doctrina sostienen esta opinión: José Antonio CoвACHo-Gómez, La deuda alimenticia, 
Con todo, habrá que entender que la obligación de socorro y ayuda durante la vigencia del vínculo va mucho más allá, por lo que no se reduce a la estricta obligación alimentaria prevista en los artículos 411 del Código Civil colombiano y ss ${ }^{32}$. Segunda, la obligación alimentaria legal prevista para después de la ruptura del vínculo en el punto 4 del artículo 411 del Código Civil colombiano supone, entendida desde un punto innovador, la previsión del establecimiento de una pensión alimentaria para los excónyuges. Esta configuración de una obligación con finalidad alimentaria pensada para después de la ruptura creemos, en atención al tenor literal del artículo, que debería ser declarada inexequible por la Corte Constitucional en razón de una vulneración del principio de igualdad ante la ley ${ }^{33}$. Si el legislador ha pretendido salvaguardar la subsistencia vital de los excónyuges, la condición de estado de necesidad puede presentarse tanto en el culpable como el no culpable de la ruptura del vínculo. Por ende, condenar a uno de los miembros de la relación, en este caso al culpable, a no poder ejercitar una acción que le permita disponer del mínimo para subsistir ${ }^{34}$ — de modo que no le quede otro camino más allá que sobrepasar la barrera de la indigencia — resulta a todas luces ya no solo no igualitaria, sino atentatoria contra el inviolable derecho a la vida ${ }^{35}$ y la dignidad de la persona; pues ha

15 (Editorial Montecorvo, Madrid, 1990). María Ángeles García-García, El deber de actuar en interés de la familia, 68 Revista de Derecho Privado, 243-277, 245 (1984). María del Carmen Pastor-Álvarez, El deber de contribución a las cargas familiares constante matrimonio, 130 (Universidad de Murcia, Murcia, 1998).

32 Mantiene una afirmación similar a la aquí sostenida, desde el derecho español, JosÉ LuIs LACRUZ-BERDEJo, Los deberes reciprocos del artículo 68 CC y su significado actual, en Homenaje a Luis Martín-Ballesteros (Zaragoza, 1983).

33 El poder constituyente ha entendido el principio de la igualdad como un principio constitucional al cual ha de otorgársele protección y garantía. Así se desprende del artículo 13 de la Constitución Política [Const], 7 de julio de 1991. Versión corregida, 116 Gaceta Constitucional, 20 de julio de 1991, disponible en: http://www.secretariasenado.gov.co/senado/basedoc/ constitucion_politica_1991.html

34 Al respecto de esta cuestión en el ordenamiento jurídico español, atiéndase lo expuesto por María Paz García-Rubio: "La rancia fórmula utilizada en el artículo 142 [del Código Civil español] no lleva necesariamente a la equiparación de los alimentos con el mínimo vital imprescindible, más allá del cual solo queda la indigencia”. María Paz García-Rubio, Alimentos entre cónyuges y entre convivientes de hecho, 114 (Civitas, Madrid, 1995).

35 La inviolabilidad del derecho a la vida forma parte del catálogo de derechos fundamentales garantizados en el artículo 11 de la Constitución Política [Const], 7 de julio de 1991. Versión corregida, 116 Gaceta Constitucional, 20 de julio de 1991, disponible en: http://www.secretariasenado.gov.co/senado/basedoc/constitucion_politica_1991.html 
de establecerse que la idea subyacente en la obligación alimentaria gira en torno a la protección de los derechos de la personalidad ${ }^{36}$.

Aun pudiendo realizarse un análisis exhaustivo de la obligación alimentaria entre cónyuges y convivientes en atención a los diversos estadios por las que atraviesa el vínculo jurídico matrimonial o convivencial, esta no es la materia objeto de estudio que atrae la atención en esta breve disquisición. Una vez puesto de manifiesto cómo opera la relación de causalidad en la obligación ex lege alimentaria entre cónyuges, como presupuesto fundamental de su exigibilidad, hemos de tender a esclarecer si se dan las mismas consideraciones en lo que respecta a la porción conyugal o convivencial.

Al respecto del vínculo causal en la porción conyugal o convivencial cabe afirmar que, de entrada, la necesidad de existencia de ese vínculo deriva de la propia intitulación de la institución. De esta manera, al margen de la posterior consideración de pobreza, para que tenga lugar la vocación y delación hereditaria respecto a los derechos sucesorales que integran la porción, será requisito indispensable la existencia del vínculo en el momento del deceso del causante ${ }^{37}$. Ahora bien, a diferencia de lo que sucede con la obligación alimentaria, la titularidad sobre la mera expectativa a la institución hereditaria en la porción (la cual se hace depender de la concurrencia de las circunstancias de pobreza) se extiende a los vínculos de causalidad presentes - esto es, cónyuge y compañero permanente- No obstante se contempla una excepción al respecto del cónyuge separado de cuerpos, el cual será llamado como titular del derecho a la porción conyugal, siempre y cuando no converja en su figura la cualidad de culpable, en consideración al cese de la convivencia ${ }^{38}$.

Al margen de estas posibles vulneraciones que pudieran afectar al principio de igualdad ante la ley en consideración a los sujetos intervinientes, tanto en la relación obligacional alimentaria inter

36 Al libre desarrollo de la personalidad se ha referido el constituyente al incluirlo como un Derecho fundamental tutelado en el artículo 16 de la Constitución Política [Const], 7 de julio de 1991. Versión corregida, 116 Gaceta Constitucional, 20 de julio de 1991, disponible en: http:// www.secretariasenado.gov.co/senado/basedoc/constitucion_politica_1991.html

37 El legislador ha previsto la improcedencia de la porción conyugal considerada en un momento posterior al del fallecimiento del de cuius, aun cuando sobrevenga la situación de pobreza, artículo 1233 del Código Civil colombiano.

38 Esta regla de exclusión referente al separado de cuerpos culpable aparece en el artículo 1231 del Código Civil colombiano in fine. 
vivos como en la institución hereditaria que supone la porción conyugal o convivencial, cabe hacer una última precisión en consideración al vínculo causal que nos permitirá deslindar la porción conyugal de la naturaleza propia de las obligaciones alimentarias; de este modo, hemos de acudir al fenómeno de la concurrencia de vínculos que se produce en el derecho sucesoral, al respecto de una misma cuota, y que no cabe en el derecho alimentario ex lege, en el cual nacen obligaciones individuales para cada uno de los titulares.

Como se viene poniendo de manifiesto, el ordenamiento jurídico reconoce de forma concurrente derechos sucesorales en la sucesión del causante al cónyuge, al cónyuge separado de cuerpos no culpable de la ruptura de la convivencia y al compañero permanente sobreviviente. Esta circunstancia provoca una situación fáctica y jurídica impensable en otros ordenamientos jurídicos como el español, en el cual la separación judicial o de hecho impide el llamamiento sucesoral al excónyuge supérstite ${ }^{39}$, pues existen dos sujetos de derecho llamados a una misma institución hereditaria en virtud de vínculos matrimoniales o convivenciales diversos.

En Colombia, esta concurrencia se deriva, a nuestro parecer, de la defectuosa regulación de las uniones maritales de hecho establecida en la Ley 54 de $1990^{40}$, ya que de la correlación de sus artículos 1 y 2 se introduce la posibilidad de existencia de la unión marital de hecho entre personas con impedimento para contraer matrimonio, es decir, personas con un vínculo matrimonial vigente. Esta idea encuentra su refuerzo en el artículo 2 apartado segundo, al establecer una presunción iuris tantum a favor de la existencia de la sociedad patrimonial cuando habiendo impedimento legal para

39 El artículo 945 del Código Civil español cuando dice respecto a la sucesión del cónyuge que "no tendrá lugar el llamamiento a que se refiere el artículo 944 si el cónyuge estuviere separado judicialmente o de hecho". España, Real Decreto de 24 de julio de 1889 por el que se publica el Código Civil, 206 Boletín Oficial del Estado, BOE, 25 de julio de 1889. Texto consolidado disponible en: http://www.boe.es/buscar/pdf/1889/BOE-A-1889-4763-consolidado.pdf. En cuanto a la doctrina, son de destacar Carlos Lasarte-Álvarez y María del Carmen Crespo Mora. Carlos Lasarte-Álvarez, Principios de derecho civil, Tomo 7, Derecho de sucesiones, 255 (Marcial Pons, Madrid, 2015). María del Carmen Crespo-Mora, Algunos aspectos de la legítima del cónyuge viudo separado de hecho, Perspectivas de futuro, 27 BFD: Boletín de la Facultad de Derecho de la UNED (ejemplar dedicado a IV Edición Premio Artículos Jurídicos García-Goyena), 159-181 (2005). Disponible en: http://e-spacio.uned.es/fez/eserv. php?pid=bibliuned:BFD-2005-27-B07BFEA8\&dsID=PDF

40 Ley 54 de 1990, por la cual se definen las uniones maritales de hecho y régimen patrimonial entre compañeros permanentes, 39.615 Diario Oficial, 31 de diciembre de 1990. Disponible en: http://www.alcaldiabogota.gov.co/sisjur/normas/Norma1.jsp?i=30896 
contraer matrimonio por parte de uno o de ambos compañeros permanentes, haya transcurrido el lapso temporal de dos años y la sociedad o sociedades conyugales anteriores hayan sido disueltas y liquidadas por lo menos un año antes de la fecha en que se inició la unión marital de hecho.

La presente normativa, inexacta a todas luces, supone la vigencia del vínculo matrimonial previo a la constitución de la unión marital de hecho, en caso de que aquel existiese. Por consiguiente, llegamos a la situación ilógica en la que un mismo sujeto de derecho se encuentra vinculado por dos relaciones de diversa naturaleza jurídi$\mathrm{ca}^{41}$, pero ambas producen efectos en la esfera jurídico-patrimonial de aquel; no quedan excluidos, por tanto, los efectos en lo que al ámbito del derecho sucesoral se refiere, por ser este en gran parte de carácter patrimonial.

De este modo, como ya señaló en otra ocasión ${ }^{42}$, la única forma de privar al cónyuge supérstite - no cabe hablar de excónyuge, pues la relación jurídica sigue vigente al no producirse la extinción del vínculo matrimonial por la constitución de la unión marital de hecho- de sus derechos en la sucesión del de cuius es por medio de un procedimiento de indignidad, siempre y cuando hayan concurrido las causales de los numerales primero o segundo del artículo 154 del Código Civil colombiano, como se manifestaba anteriormente ${ }^{43}$.

Esta concurrencia del vínculo jurídico matrimonial con el vínculo fáctico de la unión de hecho ha llevado a la jurisprudencia a la creación de diversas teorías con el fin de determinar el alcance dentro de unos mismos derechos sucesorales — pues solo existe una única porción conyugal o convivencial - que le corresponden a

41 Del matrimonio se desprende un vínculo de naturaleza jurídica, mientras que la unión marital de hecho presenta un vínculo fáctico o de hecho derivado de la convivencia permanente.

42 “(...) los interesados en la exclusión del cónyuge supérstite deberán iniciar proceso de indignidad sucesoral, cuya sentencia en firme evitaría la presencia del cónyuge supérstite en la sucesión”. Yadira Elena Alarcón-Palacio, Reconocimiento por vía de interpretación constitucional de los derechos sucesorios del conviviente "supérstite" en Colombia, en Estudios jurídicos en homenaje al profesor José María Miquel, Vol. I, 125-168, 153 (Luis Díez-PicAzo y Ponce de León, coord., Aranzadi, Navarra, 2014). Atiéndase, también, a lo indicado por Francisco Jordano-Fraga. Francisco Jordano-Fraga, Indignidad sucesoria y desheredación, 160-175 (Rodrigo Bercovitz RodríGuez-CANo, dir., Comares, Granada, 2004).

43 En consideración a esta cuestión, y concretamente en un supuesto de infidelidad, se manifiesta en sentencia de la Corte Suprema de Justicia, Sala de Casación Civil, Proceso 2439, Sentencia de 17 de mayo de 1990. Entre la doctrina, también mantiene esta causal de divorcio como causal de indignidad, Jorge Parra-Benítez, Derecho de Sucesiones, 110 (Universidad de Medellín - Sello Editorial UDEM, Medellín, 2010). 
cada uno de los sujetos con quienes se muestra vinculado el causante. De este modo, se puede hablar de las siguientes construcciones ${ }^{44}$ :

a) Primacía del cónyuge supérstite: esta tesis parte del predominio del cónyuge respecto al compañero, basándose en la prohibición de las situaciones de amancebamiento, por lo que entendido el concubinato como un yacimiento contrario a los principios integrantes de la causa que motiva el régimen matrimonial, habrá de darse un mayor influjo a la figura del cónyuge frente a la del compañero permanente ${ }^{45}$.

b) Relación material: debe partirse de la consideración de que esta construcción responde al campo del derecho de la seguridad social, lo que muestra a su vez una doble interpretación a la hora de resolver las cuestiones relativas a la pensión de viudedad. Así, de una parte, nos encontramos con la "prioridad del vínculo material respecto al vínculo formal”, según la cual habrá de reconocerse una igualdad entre el cónyuge y el compañero sobreviviente del de cuius, mientras el legislador atiende a un criterio material - la convivencia efectiva al momento de la muerte- para determinar la legitimación respecto a la prestación de contenido económico que se deriva del trabajo del causante ${ }^{46}$. Por otra parte, ha de mencionarse el criterio de la "proporcionalidad en los supuestos de concurrencia material de vínculos", con base en el mismo será criterio preponderante la proporcionalidad del tiempo de convivencia para determinar el alcance del derecho sucesorio entre cónyuge y compañero permanente ${ }^{47}$.

44 Yadira Elena Alarcón-Palacio, Reconocimiento por vía de interpretación constitucional de los derechos sucesorios del conviviente "supérstite" en Colombia, en Estudios jurídicos en homenaje al profesor José María Miquel, Vol. I, 125-168 (Luis Díez-Picazo y Ponce de León, coord., Aranzadi, Navarra, 2014).

45 Esta tesis responde al modelo primigenio adoptado en resoluciones de la Corte Suprema de Justicia. Corte Suprema de Justicia, Sala de Casación Civil, Sentencia de 30 de noviembre de 1935.

46 Muestran esta corriente jurisprudencial varias sentencias de la Corte Constitucional. Corte Constitucional, Sentencia T-190-93, 12 de mayo de 1993, magistrado ponente Eduardo Cifuentes-Muñoz. Disponible en: http://www.corteconstitucional.gov.co/relatoria/1993/T-190-93.htm. Corte Constitucional, Sentencia T-266-97, 29 de mayo de 1997, magistrado ponente Carlos Gaviria-Díaz. Disponible en: http://www.corteconstitucional.gov.co/relatoria/1997/t-266-97. htm. Corte Constitucional, Sentencia T-932-08, 19 de septiembre de 2008, magistrado ponente Rodrigo Escobar-Gil. Disponible en: http://www.corteconstitucional.gov.co/ relatoria/2008/t-932-08.htm. Corte Constitucional, Sentencia T-301-10, 27 de abril de 2010, magistrado ponente Jorge Ignacio Pretelt-Chaljub. Disponible en: http://www.corteconstitucional. gov.co/relatoria/2010/t-301-10.htm

$47 \mathrm{La}$ Corte atiende esta regla de la proporcionalidad por medio de la Sentencia C-1035-08, 
c) Criterio de igualdad: el fundamento de esta teoría radica en las resoluciones del Consejo de Estado ${ }^{48}$, el cual mantiene que el alcance del derecho sucesorio que representa la porción conyugal o convivencial deberá ser dividido en partes equitativamente iguales entre el cónyuge y el compañero permanente supérstite, pues el causante venía manteniendo de forma concurrente en el tiempo la simultaneidad de vínculos. De modo que si ambos — el cónyuge y el compañero permanente- ostentan legitimación pasiva en el proceso sucesoral, habrán de concurrir en igualdad de condiciones a la vocación y delación hereditaria.

Esta convergencia de sujetos legitimados - cónyuge y compañero permanente - para reclamar unos mismos derechos hereditarios, los cuales se concretan en la porción conyugal o convivencial, no tiene lugar en sede de obligaciones alimentarias. Esto supone que estas teorías o construcciones carezcan de sentido en cuanto se trate de reclamar derechos alimentarios entre cónyuges o compañeros permanentes por vía del numeral 1 del artículo 411 del Código Civil colombiano ${ }^{49}$, o dicho de otra forma, mediante las obligaciones alimentarias establecidas por ley.

La exclusión de la concurrencia de sujetos legitimados sobre una misma obligación alimentaria deriva de la propia configuración legal de esta última, pues las obligaciones alimentarias responden a una naturaleza personal extensible tanto al deudor como al acreedor de la relación obligacional. La naturaleza intuitu personae de la obligación de contenido alimenticio se asienta en tres pilares: primero, sobre los presupuestos indispensables que han de concu-

postura ratificada posteriormente mediante auto aclaratorio A173/09. Corte Constitucional, Sentencia C-1035-08, 22 de octubre de 2008, magistrado ponente Jaime Córdoba-Triviño. Disponible en: http://www.corteconstitucional.gov.co/relatoria/2008/c-1035-08.htm. Corte Constitucional, Auto aclaratorio A-173-09, 5 de mayo de 2009, magistrado ponente Luis Ernesto Vargas-Silva. Disponible en: http://corteconstitucional.gov.co/RELATORIA/Autos/2009/ A173-09.htm

48 Consejo de Estado, Sentencia 0638-08, 30 de julio de 2009, radicado 68001-23-15000-2001-02594-01, consejero ponente Gerardo Arenas-Monsalve. Disponible en: http://190.24.134.114:8080/WebRelatoria/ce/index.xhtml. Consejo de Estado, Sentencia 165909, 27 de mayo de 2010, radicado 19001-23-31-000-2001-01669-01, consejero ponente Víctor Alvarado-Ardila. Disponible en: http://190.24.134.114:8080/WebRelatoria/ce/index.xhtml, entre otras sentencias.

49 La Corte Constitucional declaró la exequibilidad del numeral 1 del artículo 411 del Código Civil, siempre y cuando se entienda que esta disposición es aplicable a los compañeros permanentes que forman una unión marital de hecho. Corte Constitucional, Sentencia C-103302, 27 de noviembre de 2002, magistrado ponente Jaime Córdoba-Triviño. http://www. corteconstitucional.gov.co/relatoria/2002/c-1033-02.htm 
rrir para que exista la obligación de alimentos ${ }^{50}$; segundo, sobre los límites de orden público que se representan a través del carácter de indisponibilidad ${ }^{51}$ y tercero, sobre la finalidad asistencial de la propia institución ${ }^{52}$.

En consideración a esta naturaleza personalísima que presenta la obligación, no cabe hablar de una posible concurrencia de sujetos legitimados - aun cuando el vínculo matrimonial no se haya disuelto y haya una unión marital de hecho-- pues cada uno de ellos (esto es, el cónyuge y el compañero permanente) tendrá un derecho propio a reclamar alimentos a un único deudor alimenticio

50 Para poder hablar de obligación alimentaria es necesaria la concurrencia de una serie de presupuestos, sobre los cuales se asienta esa relación obligatoria. El primero de estos requisitos es la presencia de un vínculo entre el alimentante y el alimentario. No se trata de una obligación erga omnes, sino que la única posibilidad subjetiva de construir esta obligación ex lege consiste en que medie una relación o vínculo. Sin embargo, no basta con la concurrencia del vínculo subjetivo para hablar de obligación de alimentos, ya que, además, habrán de darse dos presupuestos objetivos: el estado de necesidad en el alimentario y la capacidad o posibilidad económica del alimentante.

51 Como se ha señalado anteriormente, la obligación legal de alimentos participa de un carácter público-privado, del que se derivan ciertos límites de orden público. Estos límites se manifiestan en la obligación alimentaria a la que se atribuye el carácter de indisponible, tanto inter vivos como mortis causa, que a su vez configura a la relación obligatoria como intuitu personae. En cuanto que, como señala Antonio Cicu, la intransmisibilidad pasiva se debe a la cualidad de la persona obligada y, debido a su estrecha y continua dependencia de la obligación, a la condición patrimonial del obligado. Antonio CICU, La natura giuridica dell'obbligo alimentare fra congiunti, 2 Rivista di diritto civile, Milano, 0, 145-194, 165 (1910). Nos encontramos, por ello, ante una obligación que se puede calificar simultáneamente de personal por su fuente y de patrimonial-personal por su concepto: Ferrán BADOSA I Coll, Comentaris a les Reformes del Dret Civil de Catalunya, Volumen I, 48 (Editorial Bosch, Barcelona, 1987). Como señala Adoración Padial-Albás: "La persona obligada no puede desvincularse del mandato legal, de modo que, no es, tampoco, admisible la novación por cambio de deudor, ni aun con el consentimiento del alimentista". Adoración PADIAL-Albás, La obligación de alimentos entre parientes, 166 (Editorial Bosch, Barcelona, 1997). Por otra parte, si el fundamento último o última ratio de la obligación alimentaria es la protección de los derechos de la personalidad, incluyéndose entre estos el derecho a la vida, parece lógica la limitación a su renuncia, entendida esta como el acto por el que el titular hace dejación voluntaria de su derecho.

52 La naturaleza personalísima de la obligación de alimentos entre parientes descansa en la propia finalidad de la institución. A pesar del contenido patrimonial, la relación alimentaria surge con la intención de cubrir las necesidades del acreedor y, por lo tanto, su subsistencia. Este fin último de la obligación alimentaria contribuye a alejarla de las obligaciones patrimoniales, pues la obligación está íntimamente ligada a las características o condiciones personales de los sujetos intervinientes.

Aunque es posible el establecimiento de obligaciones patrimoniales con base en circunstancias personales de los intervinientes, estas obligaciones no están indisolublemente conexas a la persona de su titular. Esta conexión únicamente se presenta en la relación alimentaria, debido a la necesidad del titular del derecho de alimentos y a la capacidad económica del obligado a prestarlos, pues como señala Doménico Barbero, la prestación sirve para alimentar al necesitado y no para ser economizada. Doménico BArbero, Sistema de Derecho privado, Volumen II, 192 (Santiago Sentis-Melendo, trad., Ediciones Jurídicas Europa-América, EJEA, Buenos Aires, 1967). 
(a su cónyuge, respecto al primero, y a su compañero permanente, en consideración al segundo). Por ende, no se trata de que dos sujetos estén legitimados para reclamar unos mismos derechos como sucede con los derechos sucesorales que integran la porción conyugal—, sino que cada uno de los sujetos está legitimado para reclamar unos derechos alimentarios personalísimos que por la concurrencia de los dos vínculos (el matrimonial y el more uxorio) tienen como único deudor a un mismo sujeto de derecho.

De esta manera, cada uno de los sujetos de derecho será titular de una obligación alimentaria propia que habrá de fijarse cuantitativamente atendiendo a sus circunstancias de necesidad y a las facultades y circunstancias domésticas del deudor; por ello, extinguido el estado de necesidad o no pudiendo el deudor hacer frente a la satisfacción del crédito alimentario, la relación obligatoria se extinguirá entre esos dos sujetos de derecho que la integran. Como señala Nieves Martínez-Rodríguez, estamos ante una obligación de alimentos únicamente vinculada a dos partes concretas determinadas por sus circunstancias personales, sin que ninguna de ellas pueda ser sustituida por otra en la relación, pues entonces surgiría una obligación nueva y distinta a la anterior ${ }^{53}$.

Aplicado a la porción conyugal el vínculo de causalidad, el cual constituye uno de los requerimientos taxativos para el nacimiento de la obligación alimentaria, puede afirmarse que las circunstancias propias que la misma presenta en sede alimentaria no se adecúan o son susceptibles de encaje en la institución sucesoria. Por tal razón, ha de entenderse - sin perjuicio del posterior análisis de los restantes requerimientos de la obligación alimentaria- que resulta difícilmente atribuible a la porción conyugal o convivencial la determinación naturalística de obligación alimentaria constituida a favor del cónyuge o compañero supérstite del causante, sin perjuicio de que esta institución sucesoria responda a una finalidad alimentaria; esta cuestión no guarda relación alguna con la naturaleza.

53 Nieves Martínez-Rodríguez, La obligación legal de alimentos entre parientes, 157 (La Ley, Madrid, 2012). 


\section{El estado de necesidad, su influencia en el nacimiento de la obligación alimentaria y su configuración inexacta en torno a la porción}

A continuación, resulta necesario seguir con el análisis de los requerimientos cuya concurrencia determina la existencia de un crédito/ deuda alimentaria. El siguiente de estos elementos viene integrado por el estado de necesidad del alimentista, pues el propio legislador ha previsto que los alimentos "no se deben sino en la parte en que los medios de subsistencia del alimentario no le alcancen para subsistir de un modo correspondiente a su posición social o para sustentar la vida" ${ }^{54}$.

Dejando al margen el contenido de la prestación alimentaria, el cual por su extensión sería objeto de otra obra, cabe atender al propio concepto de "estado de necesidad" como criterio generador del derecho a reclamar alimentos ex lege. Partiendo de esta concepción, cabe afirmar que el estado de necesidad actúa como presupuesto inicial y final de la relación alimentaria, pues la obligación de dar alimentos será exigible desde que los necesitare para subsistir. Mientras que el artículo 422 del Código Civil colombiano fija el cese intrínseco de la obligación cuando las circunstancias que legitimaron la demanda dejen de existir. Por ende, el estado de necesidad determina la perfección de la obligación alimentaria, ya que el derecho a los alimentos solo se puede exigir desde que existe el estado de necesidad ${ }^{55}$. Ahora bien, debe advertirse que el estado de necesidad, considerado como presupuesto generador de la obligación, no puede llevar al lector a confundirlo con las causas originadoras del mismo: así, reveses de fortuna, imposibilidad laboral, enfermedad... Incluso, aquellas causas en las que el estado de necesidad le fuese directamente atribuible al alimentario (mala administración, negocios o juegos dependientes del alea...).

La concurrencia de esta necesidad ha de ser apreciada únicamente respecto a la persona del alimentario, quien podrá estar legitimado o no para interponer la demanda — esto es, el caso de

54 En estos términos se pronuncia el legislador por medio del artículo 420 del Código Civil colombiano. Ley 57 de 1887, Código Civil. Disponible en: http://www.secretariasenado.gov. co/senado/basedoc/codigo_civil.html

55 En este sentido, Felipe Sánchez-Román, Estudios de Derecho Civil, Tomo V, Volumen II, 1264 (Establecimiento Tipográfico Sucesores de Rivadeneyra, Madrid, 1912). 
alimentos a favor de un menor de edad que aun siendo titular del derecho de alimentos, habrá de actuar por medio de su representante legal para el ejercicio de ese derecho-. Esta circunstancia, de carácter objetivo, responde a una vinculación personalísima con el derecho de subsistencia del titular del crédito alimentario, de ahí que para su apreciación hayan de excluirse las circunstancias familiares donde aquel se encuadra ${ }^{56}$.

Así, resulta necesario pensar que habrá de hablarse de necesidad cuando al alimentario no le sea factible, por sí mismo, sufragar sus necesidades, ya sea por medio del gasto de sus bienes patrimoniales ya mediante las rentas de su trabajo. No obstante, para hablar de estado de necesidad no basta con que el sujeto apriorísticamente titular de la expectativa del derecho de alimentos carezca de capital, rentas o bienes para subvenir a sus necesidades; sino que, además, será preciso que no se encuentre en condiciones de incorporarse al mercado laboral ${ }^{57}$. Esta última condición representa una clave de bóveda en la determinación del estado de necesidad, pues como señala Pablo Beltrán de Heredia "quien puede trabajar no tiene derecho a exigir que otros le mantengan"58. en consecuencia, el alimentante — que resultaría obligado por la relación alimentaria- podrá alegar en contra de la constitución de la obligación que resulta indefectible obligar a trabajar al alimentario para cubrir sus necesidades si esta circunstancia no está presente en la vida del acreedor.

Lo expuesto anteriormente requiere una matización en lo que respecta al cónyuge, compañero permanente o ascendientes, ya que generalmente resulta más factible la incorporación al mercado laboral de los descendientes por tener una mayor trayectoria ad futurum de carácter laboral. Por tal razón, el juzgador deberá atender a las circunstancias del caso concreto para determinar o no

56 María Ángeles Fernández González-Regueral mantiene esta misma postura. MARía ÁngELES FERnÁNDEZ GonzÁlez-Regueral, El derecho y el deber de alimentos de las personas mayores, 4 Actualidad Civil, 1447-1452 (2001).

57 Corte Constitucional, Sentencia T-285-10, 19 de abril de 2010, magistrado ponente Gabriel Eduardo Mendoza-Martelo. Disponible en: http://corteconstitucional.gov.co/ relatoria/2010/T-285-10.htm

58 Pablo Beltrán de Heredia, Rodrigo Bercovitz Rodríguez-Cano \& José María CastánVÁzQuez, Comentarios al Código Civil y compilaciones forales, Tomo III, Vol. II: artículos 142 a 180, 26 (Manuel Albaladejo, dir., Editoriales de Derecho Reunidas, EDERSA, Madrid, 1982). 
la concurrencia de ese estado de necesidad, pues en determinadas ocasiones el alimentario presenta características propias que, aun teniendo posibilidad física de trabajar, por su edad o su formación profesional le pueden resultar un obstáculo para encontrar empleo. De esta forma, no cabe privar de alimentos a quien pudiendo y queriendo trabajar no encuentra un empleo adecuado a su oficio, profesión o carrera ${ }^{59}$.

Una vez determinado el planteamiento del estado de necesidad respecto a la obligación de alimentos, resulta necesario trasladar la concepción de necesidad a la figura del cónyuge o compañero supérstite. El presupuesto material de la porción conyugal es un derecho de carácter sucesoral y el propio legislador prevé esta naturaleza al colocar la porción conyugal dentro del Libro Tercero del Código Civil, destinado a la sucesión por causa de muerte ${ }^{60} ; \mathrm{y}$ concretamente viene a reforzar esta idea el artículo 1230 del Código Civil colombiano al incluir el término "asignación" dentro de la conceptualización de la figura jurídica. Sin embargo, se trata de un derecho sucesoral que lejos de configurarse como absoluto o incondicional está supeditado a que el conviviente en pareja estable o el cónyuge del causante cumplan una doble condición: primero, al propio estado de congrua subsistencia - que el cónyuge o el conviviente sobreviviente no tengan recursos suficientes para satisfacer sus necesidades - y, segundo, a la condición de "pobreza". Háblese de doble condición porque puede o no coincidir el estado de necesidad con la condición de pobreza, de modo que puede darse el caso de que al cónyuge o al conviviente del causante aun

59 Resulta interesante al respecto de esta cuestión la sentencia del Tribunal Supremo español, que se pronuncia en los siguientes términos: "Es preciso que el ejercicio de la profesión, oficio o industria sea una posibilidad concreta y eficaz, según las circunstancias, no una mera capacidad subjetiva”. España, Tribunal Supremo, Sentencia de 5 de noviembre de 1984. Y las siguientes sentencias: España, Tribunal Superior de Justicia y Audiencia Provincial SAP - de Murcia, Sentencia de 16 de febrero de 1999. España, Tribunal Superior de Justicia y Audiencia Provincial — SAP — de Badajoz, Sentencia de 25 de noviembre de 2000. España, Tribunal Superior de Justicia y Audiencia Provincial - SAP — de Asturias, Sentencia de 26 de febrero de 2001. España, Tribunal Superior de Justicia y Audiencia Provincial - SAP — de Castellón, Sentencia de 5 de enero de 2004. España, Tribunal Superior de Justicia y Audiencia Provincial - SAP — de Castellón, Sentencia de 28 de junio de 2005. España, Tribunal Superior de Justicia y Audiencia Provincial - SAP — de Salamanca, Sentencia de 3 de noviembre de 2009.

60 Título V del Libro III del Código Civil Colombiano, en el cual se contempla la porción conyugal como una asignación dentro del de cuius succesione agitur. Ley 57 de 1887, Código Civil. Disponible en: http://www.secretariasenado.gov.co/senado/basedoc/codigo_civil.html 
estando necesitados de la porción conyugal para subsistir, no les sea reconocido este derecho sucesoral porque sus otros bienes y derechos exceden el límite establecido para ostentar la condición de "pobre" o viceversa.

Dicho lo anterior, ha de hacerse una precisión: el condicional al estado de necesidad del cónyuge o conviviente resulta mera utopía, pues el legislador no establece un criterio de cuantificación objetiva y subjetiva de la porción, esto es atendiendo a las reales y efectivas necesidades congruas del cónyuge o conviviente supérstite, sino que se fija el monto de forma invariable en atención a la concurrencia del derecho con el orden sucesoral ${ }^{61}$. Esta falta de elementos que permitan determinar las necesidades del cónyuge o del conviviente acreedor ${ }^{62}$, provoca que el presupuesto de estado de necesidad, tal y como se configura en las obligaciones de carácter alimentario, no sea aplicable a la porción conyugal ${ }^{63}$. En el derecho sucesorio,

61 En atención a este aspecto, baste acudir al artículo 1236 del Código Civil colombiano.

62 A estos elementos hace referencia el Código Civil de Cataluña en su artículo 452-1.2 al regular la institución de la cuarta vidual, considerada como fundamento originario de la porción conyugal o de pareja. El legislador catalán reza así: "Per a determinar les necessitats del cònjuge o del convivent creditor, s'ha de tenir en compte el nivell de vida de què gaudia durant la convivència i el patrimoni relicte, i també la seva edat, l'estat de salut, els salaris o rendes que estigui percebent, les perspectives econòmiques previsibles i qualsevol altra circumstància rellevant" (Para determinar las necesidades del cónyuge o del conviviente acreedor, debe tenerse en cuenta el nivel de vida de que disfrutaba durante la convivencia y el patrimonio relicto, así como su edad, el estado de salud, los salarios o rentas que esté percibiendo, las perspectivas económicas previsibles y cualquier otra circunstancia relevante [traducción propia]). España, Código Civil de Cataluña. Disponible en: http://civil.udg.es/normacivil/cat/CCC/ES/Index.htm

$63 \mathrm{Al}$ respecto de esta diferenciación entre la obligación de naturaleza alimenticia y el derecho sucesoral en que consiste la porción del cónyuge o conviviente, Santiago Espiau-Espiau señala: “(...) el dret a la quarta vidual presenta alguna característica que el diferencia del dret d'aliments en sentit estricte: en primer lloc, les necessitats a satisfer tenen caràcter relatiu, ja que vénen determinades fonamentalment per la situació del seu beneficiari constant matrimoni o durant la convivència amb el cònjuge o el convivent premorts; en segon lloc, el beneficiari del dret a la quarta vidual té béns i recursos propis i no es troba necessàriament en la situació de precarietat que pressuposen en l'alimentant els arts. 261; i finalment, la satisfacció de les necessitats a què s'orienta el dret a la quarta vidual no permet que el patrimoni que ha d'atendre-les es faci càrrec íntegrament d'elles, sinó només fins a un determinat límit o quantia: el corresponent a la quarta part del seu valor" (... el derecho a la cuarta vidual presenta algunas características que lo diferencian del derecho de alimentos en sentido estricto: en primer lugar, las necesidades a satisfacer tienen carácter relativo, ya que vienen determinadas fundamentalmente por la situación de su beneficiario constante matrimonio o durante la convivencia con el cónyuge o el conviviente premuertos; en segundo lugar, el beneficiario del derecho a la cuarta viudal tiene bienes y recursos propios y no se encuentra necesariamente en la situación de precariedad que presuponen en el alimentando los arts. 261; y finalmente, la satisfacción de las necesidades a las que se orienta el derecho a la cuarta vidual no permite que el patrimonio que debe atenderlas se haga cargo íntegramente de ellas, sino solo hasta un determinado limite o cuantía: el correspondiente a la cuarta parte de su valor [traducción propia]). SANTIAGo EsPiau-EsPiau, Comentari al article 452-1, en Comentari al llibre quart del Codi Civil de Catalunya, relatiu a les successions, Vol. II, 
el estado de necesidad no determina el inicio y el fin de la relación obligacional, como sí sucede en las obligaciones de naturaleza alimentaria, sino que únicamente constituye una entelequia o ficción para determinar la posibilidad ex ante de adquirir la expectativa a ese derecho sucesoral; mientras que la estimación de la pobreza es el elemento determinante para la real adquisición del derecho a la porción conyugal o convivencial.

Por ende, cabe adelantar que, en nuestro criterio, la porción conyugal es — cumplida la condición de pobreza - a todas luces una institución hereditaria universal o de cuota ${ }^{64}$ en todos los órdenes sucesorales de la sucesión ${ }^{65}$, tanto testamentaria como $a b$ intestato $^{66}$; institución hereditaria que no ha de confundirse con el llamamiento a heredar, pues en la figura del cónyuge o conviviente del causante podrían concurrir simultáneamente ambos derechos

1447-1449 (Joan Egea i Fernández \& Josep Ferrer i Riba, dirs., Laura Alascio-Carrasco, coord., Atelier, Barcelona, 2009).

64 La redacción del artículo 1238 del Código Civil colombiano refuerza esta idea cuando establece una responsabilidad al cónyuge o conviviente supérstite equiparable a la de los demás herederos, en atención a sus respectivas cuotas en la sucesión del causante. Del mismo modo, podrá considerarse una institución hereditaria a título singular, ya que se le puede instituir heredero respecto a un bien o derecho concreto de la sucesión, en este caso resultaría aplicable la responsabilidad a que se refiere el artículo 1238 del Código Civil colombiano in fine, equiparable a la responsabilidad de los legatarios.

65 La Corte Suprema de Justicia mantiene una postura contraria a la aquí defendida. Sentencia de Casación, al disponer que "(...) lo que el cónyuge sobreviviente recibe por porción conyugal no es a título de heredero. Su condición jurídica es diversa a la de este (...)". Corte Suprema de Justicia, Sala de Casación Civil, Sentencia de 21 de marzo de 1969.

66 El legislador en el artículo 1226 del Código Civil colombiano contempla la porción conyugal o de pareja como una asignación forzosa, lo que supone que deba ser considerada y respetada con independencia del carácter de la sucesión (testamentaria o intestada). Al igual que sucede con la limitación a la capacidad testamentaria que deriva de las legítimas. Esta distinción y aplicación a ambas clasificaciones sucesorias aparece ya recogida por algunos autores, entre los que destaca Roberto Suárez-Franco, al indicar: "La materia de la porción conyugal no corresponde por lo demás al título 4 del libro 3 del Código Civil, que versa sobre las 'asignaciones testamentarias' sino que hace parte del título 5. 'De las asignaciones forzosas', cuyas disposiciones cobijan por igual las sucesiones testamentarias y abintestato". RoBERTO SuÁrez-Franco, Derecho de sucesiones, 311 (Editorial Temis, Bogotá, 2007). 
sucesorales ${ }^{67}$ y no por ello la condición de heredero ha de excluir la de titular del derecho a la porción conyugal ${ }^{68}$.

A pesar de lo dispuesto anteriormente, resulta necesario hacer una puntualización respecto al cómputo de los elementos que han de ser tenidos en cuenta a efectos de valorar la situación de pobreza — situación de la que depende la transformación de la porción conyugal de una mera expectativa a una titularidad jurídica efectiva- dado que, aun siendo derechos hereditarios o sucesorales distintos, la porción de masa hereditaria que el cónyuge o conviviente haya de recibir a título de heredero habrá de ser computada para determinar si concurre o no la condición de "pobre".

Dicho de otro modo, si tenidos en cuenta la mitad de los bienes gananciales del cónyuge o de los bienes patrimoniales del conviviente, los bienes propios del titular de la expectativa del derecho a la porción conyugal o del conviviente more uxorio, los que deriven de su condición de heredero en los órdenes hereditarios segundo o tercero y la pensión de jubilación, se excede el monto de lo que correspondería a la porción conyugal o convivencial, no cabrá hablar de situación de pobreza y por lo tanto, la expectativa del derecho sobre la porción no da lugar a una verdadera titularidad respecto a ese derecho sucesoral ${ }^{69}$.

67 Esta circunstancia de concurrencia de derechos sucesorales se da en el segundo y tercer orden hereditario, pues en ambos el cónyuge está llamado como heredero y, si se da la circunstancia de pobreza, como titular del derecho a la porción conyugal o convivencial. El artículo 1234 del Código Civil colombiano establece la imputación a título de porción conyugal o de pareja respecto a todo lo que el cónyuge o conviviente sobreviviente tuviere derecho a percibir por cualquier otro título en la sucesión del difunto. No obstante, parece ilógico computar dentro de un derecho hereditario las atribuciones que por ley le corresponden al cónyuge o conviviente por otro derecho sucesoral como es la condición de ser heredero, privándole así de los derechos adquiridos y derivados de esta última.

68 Son dos derechos sucesorios independientes, así los reconoce el artículo 1226 del Código Civil colombiano, y en cuanto exceda el límite establecido para el monto de la porción conyugal habrá de atribuirse a la cuarta de libre disposición — art. 1237 del Código Civil colombiano-; sin perjuicio de las reducciones oportunas a efectos de salvaguardar los derechos de los demás legitimarios.

69 En torno a los "Pressupòsits econòmics", adviértase lo señalado por José Luis Llaquet de Entrambasaguas, al decir: "(...) han de realitzar-se unes operacions comptables per calcular el patrimoni del supervivent (béns propis, béns adquirits per raò de la liquidació del règim econòmic matrimonial i bèns atribuïts pel causant de la mort o en consideració de la mateixa)" (... deben realizarse unas operaciones contables para calcular el patrimonio del superviviente (bienes propios, bienes adquiridos por razón de la liquidación del régimen económico matrimonial y bienes atribuidos por el causante de la muerte o en consideración de la misma) [traducción propia]). José Luis Llaquet de Entrambasaguas, La Quarta Vidual, en Dret Civil Català, Vol. III, Dret de Successions, 406-407 (Adolfo Lucas-Esteve, dir., Bosch Civil, Barcelona, 2010). Disponible en: http://jllaquet.jimdo.com/publicaciones/cap\%C3\%ADtulos-de-libros/ 
Cabe incluir las pensiones de jubilación públicas o privadas en el cómputo de la determinación de pobreza, pues la lógica de la institución de la porción no permite entender que el supérstite está desamparado, si su futuro queda asegurado dentro de un régimen de jubilación privada o pública. Más discutible con el espíritu de la porción resulta la imputación de las rentas del trabajo, aun cuando ofrezcan las suficientes garantías de estabilidad para que se puedan estimar como medios de vida seguros y vitalicios del cónyuge o compañero supérstite, por lo que no han de ponderarse en el quantum que permite o no la congrua sustentación.

La calificación de la figura sucesoral como un derecho de alimentos quiebra, en torno al concepto de necesidad, con la limitación temporal establecida por el legislador para la determinación de la condición de pobreza ${ }^{70}$. Esta circunstancia impide, definitivamente, que pueda hablarse de la porción conyugal o convivencial como un derecho con carácter alimentario que se conceda al cónyuge o compañero permanente derivado de la sucesión del otro, teniendo en cuenta su falta de apreciación al estado de necesidad. Entendemos que nos encontramos ante un derecho autónomo y temporal, contemplado ex lege y que se establece en función del patrimonio del causante.

\section{La capacidad económica como último presupuesto esencial de la obligación alimentaria. Su aplicabilidad a la porción conyugal o convivencial}

Hemos de concluir con el análisis del último elemento o presupuesto integrante de la obligación alimentaria: la capacidad económica del deudor o, dicho de otro modo, la consideración a las facultades del deudor y sus circunstancias domésticas.

El legislador hace referencia a esta capacidad económica del alimentante a la hora de referirse a la tasación de los alimentos — artículo 419 del Código Civil colombiano-. No obstante, ha de

70 El legislador ha previsto que la consideración de la condición de pobreza habrá de ser determinada al tiempo de fallecer el causante de cuya sucesión se trate, de modo que una vez superado este tiempo, aun cuando el compañero permanente o el cónyuge devenga en una situación de necesidad, no habrá derechos sucesorios a favor de los inicialmente titulares sobre dicha expectativa. Adviértase, en este sentido, lo dispuesto en el artículo 1233 del Código Civil colombiano. 
creerse que esta correlación no es del todo exacta por dos motivos: el primero de ellos deriva de la propia consideración de la capacidad del deudor como un presupuesto objetivo para el nacimiento de la obligación alimentaria, pues si el deudor no tiene una solvencia económica que le permita hacer frente a la satisfacción del crédito alimentario difícilmente podrá este nacer respecto al mismo, aun cuando se presente una necesidad de subsistencia del alimentario, sino que la relación obligacional habrá de surgir frente a los demás obligados conforme a la prelación de titulares ${ }^{71}$. Ello no impide que puedan concurrir diversas relaciones obligatorias de carácter alimentario, cuando la capacidad económica de uno de los deudores, por sí mismo, no sea suficiente para atender las necesidades del alimentario.

El segundo de los argumentos que se esgrime radica en que la propia tasación de los alimentos - aun debiendo de ser considerada en relación con las facultades del alimentante y sus circunstancias domésticas - no ha de ser equiparable a las condiciones de vida de que viene disfrutando el alimentante. Es decir, no se trata únicamente de cuantificar y cualificar los alimentos con base en la capacidad económica del deudor y la necesidad del acreedor alimentario; más allá de la tasación tendiente a asegurar la congrua subsistencia será necesario aplicar el criterio de la racionalidad de los medios empleados al valorar la faceta cualitativa de los alimentos. Recuérdese que la labor del alimentante consiste en procurar al alimentario unas condiciones de vida digna cubriendo sus necesidades más indispensables, pero ello no implica que haya que sufragar unas condiciones de vida iguales o equivalentes a las que goza el propio deudor ${ }^{72}$.

En resumen, la capacidad económica del deudor de alimentos juega como un presupuesto objetivo a la hora de determinar el nacimiento de la relación obligacional, aunque de una forma menos intensa que la presentada por el estado de necesidad del alimentario, y permite establecer la pauta o criterio conforme al cual se han

71 El artículo 416 del Código Civil colombiano establece el orden de prelación de derechos alimentarios entre diversos titulares.

72 Nieves Martínez-Rodríguez apunta que todo lo que exceda de las concretas prestaciones previstas para satisfacer el mínimo vital de necesidad, será un acto de liberalidad y no forma parte del contenido de la deuda alimenticia. Nieves Martínez-Rodríguez, La obligación legal de alimentos entre parientes, 427 (La Ley, Madrid, 2012). 
de prestar dichos alimentos; esto es: de acuerdo a las facultades y circunstancias domésticas del alimentante, siempre que se apliquen principios de racionalidad.

Establecido el análisis del último de los requerimientos taxativos que determinan el nacimiento y existencia de la obligación alimentaria surge la indefectible necesidad de determinar su aplicación a la porción conyugal o de pareja, pues las diversas resoluciones atribuyen a esta la naturaleza alimenticia de aquella. Por eso, ha de verse cuál es el elemento material sobre el que recae el derecho sucesorio; dicho de otro modo, cuál es el patrimonio afectado o gravado por los derechos que integran la porción.

Como ya se adelantaba, la porción conyugal es un derecho sucesoral que grava la masa hereditaria del causante; por ende, para la determinación de la misma no entra en juego la capacidad económica del deudor - en tanto que este ya no ostenta personalidad, al haberse extinguido por el suceso del deceso-, sino que habrá de estarse al caudal relicto del de cuius. Así pues, a diferencia de lo que sucede con las obligaciones de carácter alimentario para lo que atañe a la tasación de la prestación, en la porción conyugal o convivencial el monto ya viene predeterminado por el legislador.

En consecuencia, el derecho sucesoral que constituye la porción conyugal o convivencial se extiende a la cuarta parte de los bienes relictos ${ }^{73}$, salvo en el primer orden sucesoral en el que se limita a la legítima rigurosa de un hijo ${ }^{74}$. En este orden sucesoral, el cónyuge o compañero permanente será instituido legatario ex lege de una cuota equivalente a la legítima de los hijos que ostentan la condición de legitimarios. Si bien es cierto que en el primer orden sucesoral el cónyuge no puede ser considerado legitimario en la sucesión $a b$ intestato, ello no impide considerar su asignación forzosa como una institución de heredero de cuota ex lege; pues el propio legislador le ha impuesto, como consecuencia de esa asignación a título de

73 El monto de la porción conyugal o convivencial ha sido determinado por el legislador en el artículo 1236 del Código Civil colombiano. De igual modo, el quantum en que se integra la porción habrá de ser detraído de la masa hereditaria bruta como una baja general de las que contempla el artículo 1016 del Código Civil colombiano. Por consiguiente, la determinación del caudal hereditario líquido, sobre el que se ejercitará la partición, se llevará a cabo tras la deducción del monto que integran los derechos sucesorales del cónyuge o compañero supérstite del causante.

74 Integran el primer orden sucesorio los hijos legítimos, los adoptivos y extramatrimoniales, conforme al artículo 1045 del Código Civil colombiano. 
porción conyugal, las mismas responsabilidades que las que vendría ostentando un legatario ${ }^{75}$. Por ende, no debe olvidarse que el propio concepto de legatario supone una institución hereditaria a título singular, de ahí que haya que hablar del titular del derecho sucesoral a la porción como un asignatario forzoso singular ya que, de no ser así, se le estará exigiendo una responsabilidad desproporcionada a su asignación forzosa ${ }^{76}$.

De este modo, el cónyuge o el compañero supérstite habrán de ser considerados herederos en el primer orden sucesorio ab intestato, no a condición de legitimario sino a razón de una institución a título singular ex lege - su porción conyugal o convivencial - que se determina en una parte equivalente a la legítima rigurosa de un hijo ${ }^{77}$.

Asimismo, aun tratándose de una institución hereditaria de cuota ex lege - por lo que el cónyuge o compañero supérstite ostentarán la condición de legatarios - goza de una primacía en la determinación de su quantum y preferencia de deducción del acervo o masa de bienes que el difunto ha dejado; mientras que el artículo 1016 del Código Civil colombiano establece que el monto en el que se integra la porción habrá de ser detraído de la masa hereditaria bruta como una baja general ${ }^{78}$. De modo que para establecer la determinación

75 Esta exigencia de responsabilidad al cónyuge o compañero supérstite aparece en el artículo 1238 del Código Civil colombiano.

76 José María Miquel-González, Legítima material y legítima formal, 49 Anales de la Academia Matritense del Notariado, Colegio Notarial de Madrid, Madrid (ejemplar dedicado a Curso 2008/2009), 493-560 (2009). Disponible en: http://www.elnotario.es/index.php/academiamatritense-del-notariado/1544-legitima-material-y-legitima-formal-0-9796865787167909

77 Esta idea es compartida por diversos sectores de la doctrina, que realizan puntualizaciones singulares. Luis Claro-Solar coincide de forma plena con la posición aquí mantenida, al decir que "la porción conyugal es siempre una cuantía de bienes que deben entregar al cónyuge los herederos en general o los legitimarios descendientes legítimos cuando concurre con ellos, es un legado". Luis Claro-Solar, Explicaciones del derecho civil chileno y comparado, Tomo XV, 338 ss. (Editorial Nascimento, Santiago de Chile, 1940). Para otros autores, como José Clemente Fabres-Fernández: "la porción conyugal íntegra, ya sea la cuarta parte de los bienes del difunto o una legítima rigurosa, es herencia, pero la porción conyugal complementaria, es legado". José Clemente Fabres-Fernández, La porción conyugal según el Código Civil chileno (Editorial Imprenta Cervantes, Santiago de Chile, 1908). Por su parte, Alfredo BarrosErrázuriz mantiene que "la porción conyugal ya sea íntegra o complementaria es siempre una parte alícuota de los bienes del difunto". Alfredo Barros-Errázuriz, Curso de Derecho civil, Tercer año, 81 (2 ${ }^{\mathrm{a}}$ parte, Editorial Nascimento, Santiago de Chile, 1931).

78 Esta consideración en cuanto a la determinación del quantum y preferencia en la deducción ha sido la que ha llevado, erróneamente a nuestro entender, a la Corte Suprema de Justicia a negar a la porción conyugal el carácter de institución hereditaria a título singular, considerando que: “(...) la porción conyugal no es asignación hereditaria, sino una especie de crédito a cargo de la sucesión, la cual se deduce como baja general del acervo bruto de la herencia en todos los órdenes de sucesión menos en el de los descendientes". Corte Suprema de Justicia, Sala de Casación Civil, Sentencia de 21 de marzo de 1969, magistrado ponente César Gómez- 
del caudal hereditario líquido sobre el que se ejercitará la partición, habrá que deducir la cuantía que integran los derechos sucesorales del cónyuge o compañero supérstite del causante en todos los órdenes de sucesión, menos en el de los descendientes.

Respecto al orden sucesoral de los descendientes, la institución de heredero a título singular ex lege - en que consiste la porción conyugal - se corresponde con la legítima rigurosa de un hijo en cuanto a la determinación de su monto, pero no gozará de primacía respecto a su deducción del caudal relicto bruto, a efectos de determinar el acervo líquido, en aplicación de lo dispuesto en el apartado 5 del artículo 1016 del Código Civil colombiano; por lo que ha de dársele el tratamiento que corresponde a la institución de un legado simple, esto es la determinación de su cuantía en consideración al acervo líquido ${ }^{79}$.

Al margen de esta consideración al primer orden sucesorio, para el cual el monto de la porción conyugal presenta una determinación particular, hemos de observar con mayor interés el segundo y el tercer orden sucesoral. En cuanto acontece al segundo de los órdenes abintestato, adviértase que el cónyuge está llamado a la sucesión del causante ${ }^{80}$, ello lo convierte en heredero a título universal respecto a ese llamamiento junto con los ascendientes de grado más próximo y los padres adoptantes del causante, concretándose la repartición del caudal líquido que ha de percibir por ese título hereditario en una división por cabezas. No obstante, junto a esa institución a título universal, el cónyuge o compañero permanente concurre como un heredero a título singular ex lege por los derechos sucesorales que se derivan de su porción conyugal o convivencial, siempre y cuando se dé el requisito de pobreza.

Estrada, CXXIX Gaceta Judicial, 2306-2308.Creemos que es un grave desatino, por parte del juzgador, llegar a la confusión de los criterios que determinan la naturaleza jurídica de una institución, con aquellos que sirven para fijar el monto y la preferencia en la deducción de esta institución jurídica, al respecto del caudal relicto.

$79 \mathrm{Al}$ respecto de este tratamiento, ha de hacerse un llamamiento al legislador a efectos de que introduzca una reforma de la normativa actual, encaminada a proteger al cónyuge o compañero permanente titular del derecho a la porción; de tal modo que en el orden sucesoral correspondiente a los descendientes exista una equiparación en el procedimiento de deducción del caudal relicto bruto, al igual que sucede en los restantes órdenes sucesorales.

80 La Corte Constitucional declaró exequible la expresión "cónyuge" siempre y cuando se entienda que ella comprende al compañero o compañera permanente de distinto sexo o del mismo sexo que conformó con el causante, a quien sobrevive, una unión de hecho. Corte Constitucional, Sentencia C-238-12, 22 de marzo de 2012, magistrado ponente Gabriel Eduardo MendozaMartelo. Disponible en: http://www.corteconstitucional.gov.co/relatoria/2012/c-238-12.htm 
Nótese, por tanto, que estamos ante dos instituciones hereditarias distintas - una a título universal y otra a título singular ex lege-, de modo que la vocación y delación hereditaria habrán de hacerse al cónyuge o compañero por razón de cada uno de estos derechos sucesorales. Ahora bien, el legislador ha previsto un límite en el artículo 1237 del Código Civil colombiano que no opera de forma excluyente sino integradora ${ }^{81}$; de modo que una institución no priva o impide el nacimiento de la otra, sino que el exceso habrá de imputarse a la parte de libre disposición.

Al respecto del tercer orden sucesoral, en este orden ocurre lo mismo que en el segundo orden con la diferencia de que el cónyuge o compañero permanente concurren a la sucesión del causante con los hermanos del mismo. Este llamamiento supone que la división del caudal líquido a repartir por título hereditario se haga a partes iguales, la mitad para el cónyuge o compañero y la otra para los hermanos ${ }^{82}$. Sin embargo, en nada difiere del segundo orden en cuanto respecta a la institución de heredero a título singular o de cuota ex lege, en relación con la porción. Siendo, del mismo modo, aplicable la limitación que se defiere del artículo 1237 del Código Civil colombiano.

A la vista de lo expuesto, puede concluirse que no resulta aplicable a la porción conyugal o convivencial el presupuesto objetivo de la capacidad económica del deudor, determinante del inicio de la relación obligatoria alimentaria. Por ende, creemos que tras el análisis de los principales caracteres propios de las obligaciones de naturaleza alimentaria y los presupuestos taxativos que imperan en

81 El límite excluyente es el contenido en el Código Civil español respecto a la materia de donaciones cuando dice “(...) ninguno podrá dar ni recibir, por vía de donación, más de lo que pueda dar o recibir por testamento. La donación será inoficiosa en todo lo que exceda de esta medida". España, Real Decreto de 24 de julio de 1889 por el que se publica el Código Civil, 206 Boletín Oficial del Estado, BOE, 25 de julio de 1889, artículo 636. Texto consolidado disponible en: http://www.boe.es/buscar/pdf/1889/BOE-A-1889-4763-consolidado.pdf. En torno al análisis de este límite a la donación, se puede confrontar lo señalado por Andrés Domínguez-Luelmo, cuando establece que: "Según el art. 763 CC, quien no tiene herederos forzosos goza de una absoluta libertad de disposición mortis causa. (...) Teniendo en cuenta que para el cálculo de la legítima se deben sumar contablemente todas las donaciones realizadas en vida por el causante (art. $818 \mathrm{CC}$.), el art. 636 aplica la misma regla que el art. 736, pero referido a los actos de disposición a título gratuito". Andrés Domínguez-Luelmo, Comentario al artículo 636, en Comentarios al Código Civil, 746-747 (Andrés Domínguez-Luelmo, dir., Lex Nova, Valladolid, 2010). La jurisprudencia del Tribunal Supremo español recoge este mismo límite, entre otras, en la Sentencia de 11 de octubre de 2005.

82 En el artículo 1047 del Código Civil colombiano se regula el "tercer orden hereditario". 
el nacimiento y fin de la relación obligacional, ha de afirmarse de forma rotunda que atribuir a la porción conyugal una naturaleza alimentaria — como así se hace en las diversas resoluciones — resulta un error de concepción y deslinde del propio derecho sucesoral en que aquella consiste. 


\section{CONCLUSIón}

Del concreto análisis realizado a lo largo de esta breve obra, debe extraerse la consideración relativa a que la porción conyugal o convivencial responde a una naturaleza sucesoral y así se demuestra con su propio enclave dentro de la sistemática del Código Civil, de modo que considerar esta institución de naturaleza alimentaria no produce más que una desvirtuación de la misma.

Como se ha podido demostrar, la porción conyugal no responde a una naturaleza alimentaria, ya que no le son de aplicación los caracteres propios de las obligaciones alimentarias, ni tampoco puede predicarse al respecto de la misma la concurrencia de los presupuestos imperativos que determinan el nacimiento del crédito-deuda alimentaria. Por ende, ha de sostenerse que continuar sosteniendo esta naturaleza en consideración a una institución propiamente de naturaleza sucesoral, no provoca más que una inseguridad jurídica y un caos referente a su integración en el ordenamiento vigente. En consecuencia, será necesario proceder a deslindar esta institución de forma definitiva frente a las instituciones de carácter alimentario.

Por tal motivo, hemos de creer que la porción conyugal o convivencial responde a un derecho sucesoral, consistente en la institución de su titular como un legatario o heredero de cuota ex lege, al respecto de todos los órdenes sucesorales; en tanto que el propio legislador le ha impuesto, como consecuencia de esa asignación a título de porción conyugal, la misma responsabilidad que la que vendría ostentando un legatario.

Ahora bien, el monto integrador de esta institución hereditaria ex lege a título singular vendrá determinado de forma particular en cuanto se refiere al primer orden sucesoral; pues aquel se corresponde con la legítima rigurosa de un hijo, mientras que en los restantes órdenes sucesorales — háblese del segundo y del tercero- la institución hereditaria de cuota, en que consiste la porción conyugal, se extiende a la cuarta parte de los bienes relictos.

Asimismo, aun tratándose de una institución hereditaria de cuota ex lege goza de primacía en la determinación de su quantum y preferencia de deducción del caudal relicto bruto como baja general - artículo 1016 del Código Civil colombiano-, de modo que habrá de deducirse la cuantía que integran los derechos sucesorales del 
cónyuge o compañero supérstite del causante en todos los órdenes de sucesión, menos en el de los descendientes; a efectos de establecer el caudal hereditario líquido, sobre el que se ejercitará la partición.

Respecto al orden sucesoral de los descendientes, la institución de heredero a título singular ex lege se corresponde con la legítima rigurosa de un hijo, en cuanto a la determinación de su monto; pero respecto a su deducción del caudal relicto bruto, ha de dársele el tratamiento que corresponde a la institución de un legado simple, esto es la determinación de su cuantía en consideración al acervo líquido.

En cuanto acontece al segundo y al tercero de los órdenes abintestato, adviértase que el cónyuge está llamado a la sucesión del causante, ello lo convierte en heredero a título universal respecto a ese llamamiento junto con los demás llamados a la sucesión del de cuius. Por consiguiente, el cónyuge o compañero permanente concurre como un heredero a título singular ex lege por los derechos sucesorales que se derivan de su porción conyugal o convivencial — siempre y cuando se dé el requisito de pobreza-y, además, como heredero a título universal, por haberse efectuado el llamamiento a la sucesión del causante.

Luego, la vocación y delación hereditaria habrán de hacerse al cónyuge o compañero por razón de cada uno de estos derechos sucesorales. Ahora bien, el legislador ha previsto un límite en el artículo 1237 del Código Civil colombiano que no opera de forma excluyente sino integradora, de modo que una institución no priva o impide el nacimiento de la otra, sino que el exceso habrá de imputarse a la parte de libre disposición.

En conclusión, estamos ante dos instituciones hereditarias distintas - una a título universal (consistente en el llamamiento a título de heredero universal en los órdenes sucesorales segundo y tercero) y otra a título singular ex lege (respecto al derecho sucesoral a que se refiere al porción conyugal que se extiende a todos los órdenes sucesorales siempre y cuando concurra la circunstancia de pobreza) - que se integran en la sucesión del causante a favor del cónyuge o compañero supérstite, cuya forma de determinación de su quantum varía en atención al orden sucesoral en que aquella se defiera. 


\section{BIBLIOGRAFÍA}

\section{Libros}

Badosa i Coll, Ferrán, Comentaris a les Reformes del Dret Civil de Catalunya, Volumen I (Editorial Bosch, Barcelona, 1987).

Barbero, Doménico, Sistema de Derecho privado, Volumen II (Santiago Sentis-Melendo, trad., Ediciones Jurídicas Europa-América, EJEA, Buenos Aires, 1967).

Barros-Errázuriz, Alfredo, Curso de Derecho civil, Tercer año (2a parte, Editorial Nascimento, Santiago de Chile, 1931).

Bello, Andrés, Código Civil de la República de Chile, tomo III (Ediciones de la Presidencia de la República, Caracas, 1973).

Beltrán de Heredia, Pablo; Bercovitz Rodríguez-Cano, Rodrigo \& Castán-Vázquez, José María, Comentarios al Código Civil y compilaciones forales, Tomo III, Vol. II: artículos 142 a 180 (Manuel Albaladejo, dir., Editoriales de Derecho Reunidas, EDERSA, Madrid, 1982).

Claro-Solar, Luis, Explicaciones del derecho civil chileno y comparado, Tomo XV (Editorial Nascimento, Santiago de Chile, 1940).

Coвасно-Gómez, José Antonio, La deuda alimenticia (Editorial Montecorvo, Madrid, 1990).

Fabres-Fernández, José Clemente, La porción conyugal según el Código Civil chileno (Editorial Imprenta Cervantes, Santiago de Chile, 1908).

Fabres-Fernández, José Clemente, Obras completas de José Clemente Fabres, Tomo II: La porción conyugal según el Código Civil chileno (Editorial Imprenta Cervantes, Santiago de Chile, 1908).

García-Rubio, María Paz, Alimentos entre cónyuges y entre convivientes de hecho (Civitas, Madrid, 1995).

García-Rubio, María Paz, La distribución de toda la herencia en legados (Un supuesto de herencia sin heredero) (Civitas, Secretariado de Publicaciones de la Universidad de León, León, 1989).

Haba-Müller, Enrique Pedro, Axiología jurídica fundamental. Bases de valoración en el discurso jurídico (Editorial de la Universidad de Costa Rica, San José de Costa Rica, 1934).

Iustinianus, Flavius Petrus Sabbatius, Novelas.

Jordano-Fraga, Francisco, Indignidad sucesoria y desheredación (Rodrigo Bercovitz Rodríguez-CANo, dir., Comares, Granada, 2004).

Lasarte-Álvarez, Carlos, Principios de derecho civil, Tomo 7, Derecho de sucesiones (Marcial Pons, Madrid, 2015).

Lledó-Yagüe, Francisco, La sucesión mortis causa: delación y la incapacidad para suceder, aceptación y repudiación de la herencia, las legítimas, las reservas, comunidad hereditaria y la partición (Dykinson, Madrid, 2012). 
Martínez-Rodríguez, Nieves, La obligación legal de alimentos entre parientes (La Ley, Madrid, 2012).

Mucius-Scaevola, Quintus, Código civil comentado y concordado extensamente, Vol. XIV (Instituto Editorial Reus, Madrid, 1949-1965).

Padial-Albás, Adoración, La obligación de alimentos entre parientes (Editorial Bosch, Barcelona, 1997).

Parra-Benítez, Jorge, Derecho de Sucesiones (Universidad de Medellín - Sello Editorial UDEM, Medellín, 2010).

Pastor-Álvarez, María del Carmen, El deber de contribución a las cargas familiares constante matrimonio (Universidad de Murcia, Murcia, 1998).

SÁnchez-Román, FeliPe, Estudios de Derecho Civil, Tomo V, Volumen II (Establecimiento Tipográfico Sucesores de Rivadeneyra, Madrid, 1912).

SÁnchez-Román, Felipe, Estudios de Derecho civil, Vol. VI-2 (Sucesores de Rivadeneyra, Madrid, 1850-1916).

Somarriva, Manuel, Evolución del Código Civil chileno (Editorial Temis, Bogotá, 1973).

SuÁrez-Franco, Roberto, Derecho de sucesiones (Editorial Temis, Bogotá, 2007).

Surdi-Casalensis, Ioannis Petri, Tractatus de alimentis plenissimus, et omni hominum generi, praesertimin praxi et foro, vtilissimus (Stephanum Camonetum, 1602).

VéLEZ, FernANDo, Estudios sobre el derecho civil colombiano, Vol. IV (Editorial Imprenta París-América, Medellín, 1909).

\section{Contribuciones en obras colectivas}

Alarcón-Palacio, Yadira Elena, Reconocimiento por vía de interpretación constitucional de los derechos sucesorios del conviviente "supérstite" en Colombia, en Estudios jurídicos en homenaje al profesor José María Miquel, Vol. I, 125-168 (Luis DíEzPicazo y Ponce de León, coord., Aranzadi, Navarra, 2014).

Domínguez-Luelmo, Andrés, Comentario al artículo 636, en Comentarios al Código Civil (Andrés Domínguez-Luelmo, dir., Lex Nova, Valladolid, 2010).

Espiau-Espiau, Santiago, Comentari al article 452-1, en Comentari al llibre quart del Codi Civil de Catalunya, relatiu a les successions, Vol. II (JoAn Egea i Fernández \& Josep Ferrer i Riba, dirs., Laura Alascio-Carrasco, coord., Atelier, Barcelona, 2009).

LaCruZ-Berdejo, José Luis, Los deberes reciprocos del artículo 68 CC y su significado actual, en Homenaje a Luis Martín-Ballesteros (Zaragoza, 1983).

Llaquet de Entrambasaguas, José Luis, La Quarta Vidual, en Dret Civil Català, Vol. III, Dret de Successions (Adolfo LucAs-Esteve, dir., Bosch Civil, Barcelona, 2010). Disponible en: http://jllaquet.jimdo.com/publicaciones/cap $\% \mathrm{C} 3 \% \mathrm{ADtulos}$-delibros/

Real-Pérez, Alicia, Comentario a los artículos 142 a 153 del CC, en Comentarios al Código Civil, Tomo II (Volumen II), 1395-1470 (Joaquín José Rams-Albesa \& Rosa María Moreno-Flórez, dirs., Bosch, Barcelona, 2000). 


\section{Revistas}

Cicu, Antonio, La natura giuridica dell'obbligo alimentare fra congiunti, 2 Rivista di diritto civile, Milano, 0, 145-194(1910).

Crespo-Mora, María del Carmen, Algunos aspectos de la legítima del cónyuge viudo separado de hecho, Perspectivas de futuro, 27 BFD: Boletín de la Facultad de Derecho de la UNED (ejemplar dedicado a IV Edición Premio Artículos Jurídicos García-Goyena), 159-181 (2005). Disponible en: http://e-spacio.uned.es/fez/eserv. php?pid=bibliuned:BFD-2005-27-B07BFEA8\&dsID=PDF

Fernández González-Regueral, María Ángeles, El derecho y el deber de alimentos de las personas mayores, 4 Actualidad Civil, 1447-1452 (2001).

García-García, María Ángeles, El deber de actuar en interés de la familia, 68 Revista de Derecho Privado, 243-277 (1984).

Ginot de Llobateras, Francisco, La responsabilidad del heredero simple por deudas y legados en el derecho común y foral, 3 Anuario de Derecho Civil, 4, 1057-1099 (1950).

Miquel-González, José María, Legítima material y legítima formal, 49 Anales de la Academia Matritense del Notariado, Colegio Notarial de Madrid, Madrid (ejemplar dedicado a Curso 2008/2009), 493-560 (2009). Disponible en: http:// www.elnotario.es/index.php/academia-matritense-del-notariado/1544-legitimamaterial-y-legitima-formal-0-9796865787167909

\section{Normatividad internacional}

España, Código Civil de Cataluña. Disponible en: http://civil.udg.es/normacivil/cat/ $\mathrm{CCC} / \mathrm{ES} /$ Index.htm

España, Real Decreto de 24 de julio de 1889 por el que se publica el Código Civil, 206 Boletín Oficial del Estado, BOE, 25 de julio de 1889. Texto consolidado disponible en: http://www.boe.es/buscar/pdf/1889/BOE-A-1889-4763-consolidado.pdf

\section{Normatividad colombiana}

Constitución Política [Const], 7 de julio de 1991. Versión corregida, 116 Gaceta Constitucional, 20 de julio de 1991, disponible en: http://www.secretariasenado. gov.co/senado/basedoc/constitucion_politica_1991.html

Ley 57 de 1887, Código Civil. Disponible en: http://www.secretariasenado.gov.co/senado/ basedoc/codigo_civil.html

Ley 54 de 1990, por la cual se definen las uniones maritales de hecho y régimen patrimonial entre compañeros permanentes, 39.615 Diario Oficial, 31 de diciembre de 1990. Disponible en: http://www.alcaldiabogota.gov.co/sisjur/ normas/Norma1.jsp?i=30896 


\section{Jurisprudencia internacional}

España, Tribunal Superior de Justicia de Valencia, Sentencia de 14 de octubre de 2002.

España, Tribunal Superior de Justicia y Audiencia Provincial - SAP — de Asturias, Sentencia de 26 de febrero de 2001.

España, Tribunal Superior de Justicia y Audiencia Provincial — SAP — de Badajoz, Sentencia de 25 de noviembre de 2000.

España, Tribunal Superior de Justicia y Audiencia Provincial — SAP — de Castellón, Sentencia de 5 de enero de 2004

España, Tribunal Superior de Justicia y Audiencia Provincial - SAP — de Castellón, Sentencia de 28 de junio de 2005.

España, Tribunal Superior de Justicia y Audiencia Provincial — SAP — de Lleida, Sentencia de 13 de octubre de 1998

España, Tribunal Superior de Justicia y Audiencia Provincial — SAP — de Murcia, Sentencia de 16 de febrero de 1999.

España, Tribunal Superior de Justicia y Audiencia Provincial — SAP — de Salamanca, Sentencia de 3 de noviembre de 2009.

España, Tribunal Superior de Justicia y Audiencia Provincial — SAP — de Santa Cruz de Tenerife, Sentencia de 22 de noviembre de 2012.

España, Tribunal Superior de Justicia y Audiencia Provincial - SAP — de Valencia, Sentencia de 23 de febrero de 2001.

España, Tribunal Supremo, Sentencia de 11 de octubre de 1982.

España, Tribunal Supremo, Sentencia de 5 de noviembre de 1984.

España, Tribunal Supremo, Sentencia de 10 de noviembre de 1987.

\section{Jurisprudencia colombiana}

Consejo de Estado, Sentencia 2410-04, 20 de septiembre de 2007, radicado 76001233100019990145301, consejero ponente Jesús María Lemos-Bustamante. Disponible en: http://consejo-estado.vlex.com.co/vid/-410740250, http://190.24.134.114:8080/WebRelatoria/ce/index.xhtml

Consejo de Estado, Sentencia 2176-07, 26 de junio de 2008, radicado 25000-23-25000-2001-02614-01, consejero ponente Gustavo Eduardo Gómez-Aranguren. Disponible en: http://190.24.134.114:8080/WebRelatoria/ce/index.xhtml

Consejo de Estado, Sentencia 0638-08,30 de julio de 2009, radicado 68001-23-15-0002001-02594-01, consejero ponente Gerardo Arenas-Monsalve. Disponible en: http://190.24.134.114:8080/WebRelatoria/ce/index.xhtml

Consejo de Estado, Sentencia 1659-09, 27 de mayo de 2010, radicado 19001-23-31000-2001-01669-01, consejero ponente VíctorAlvarado-Ardila. Disponible en: http://190.24.134.114:8080/WebRelatoria/ce/index.xhtml

Corte Constitucional, Auto aclaratorio A-173-09, 5 de mayo de 2009, magistrado ponente 
Luis Ernesto Vargas-Silva. Disponible en: http://corteconstitucional.gov.co/ RELATORIA/Autos/2009/A173-09.htm

Corte Constitucional, Sentencia C-246-02, 9 de abril de 2002, magistrado ponente Manuel José Cepeda-Espinosa. Disponible en:http://www.corteconstitucional. gov.co/relatoria/2002/C-246-02.htm

Corte Constitucional, Sentencia C-1033-02, 27 de noviembre de 2002, magistrado ponente Jaime Córdoba-Triviño. http://www.corteconstitucional.gov.co/ relatoria/2002/c-1033-02.htm

Corte Constitucional, Sentencia C-1035-08, 22 de octubre de 2008, magistrado ponente Jaime Córdoba-Triviño. Disponible en: http://www.corteconstitucional.gov.co/ relatoria/2008/c-1035-08.htm

Corte Constitucional, Sentencia C-029-09, 28 de enero de 2009, magistrado ponente Rodrigo Escobar-Gil. Disponible en: http://www.corteconstitucional.gov.co/ relatoria/2009/c-029-09.htm

Corte Constitucional, Sentencia C-283-11, 13 de abril de 2011, magistrado ponente Jorge Ignacio Pretelt-Chaljub. Disponible en: http://www.corteconstitucional.gov.co/ relatoria/2011/C-283-11.htm

Corte Constitucional, Sentencia C-238-12, 22 de marzo de 2012, magistrado ponente Gabriel Eduardo Mendoza-Martelo. Disponible en: http://www. corteconstitucional.gov.co/relatoria/2012/c-238-12.htm

Corte Constitucional, Sentencia T-190-93, 12 de mayo de 1993, magistrado ponente Eduardo Cifuentes-Muñoz. Disponible en: http://www.corteconstitucional.gov. co/relatoria/1993/T-190-93.htm

Corte Constitucional, Sentencia T-266-97, 29 de mayo de 1997, magistrado ponente CarlosGaviria-Díaz. Disponible en: http://www.corteconstitucional.gov.co/ relatoria/1997/t-266-97.htm

Corte Constitucional, Sentencia T-932-08, 19 de septiembre de 2008, magistrado ponente Rodrigo Escobar-Gil. Disponible en: http://www.corteconstitucional.gov.co/ relatoria/2008/t-932-08.htm

Corte Constitucional, Sentencia T-285-10, 19 de abril de 2010, magistrado ponente Gabriel Eduardo Mendoza-Martelo. Disponible en: http://corteconstitucional. gov.co/relatoria/2010/T-285-10.htm

Corte Constitucional, Sentencia T-301-10, 27 de abril de 2010, magistrado ponente Jorge Ignacio Pretelt-Chaljub. Disponible en: http://www.corteconstitucional.gov.co/ relatoria/2010/t-301-10.htm

Corte Suprema de Justicia, Sala de Casación Civil, Sentencia de 30 de noviembre de 1935.

Corte Suprema de Justicia, Sentencia de 18 de julio de 1944.

Corte Suprema de Justicia, Sentencia de 21 de octubre de 1954.

Corte Suprema de Justicia, Sala de Casación Civil, Sentencia de 21 de marzo de 1969, magistrado ponente César Gómez-Estrada, CXXIX Gaceta Judicial, 2306-2308.

Corte Suprema de Justicia, Sala de Casación Civil, Proceso 2439, Sentencia de 17 de mayo de 1990. 